\title{
SUITABILITY OF MICROFINANCE AS AN INVESTMENT OPTION
}

\author{
Karel Janda \\ Barbora Svárovská
}

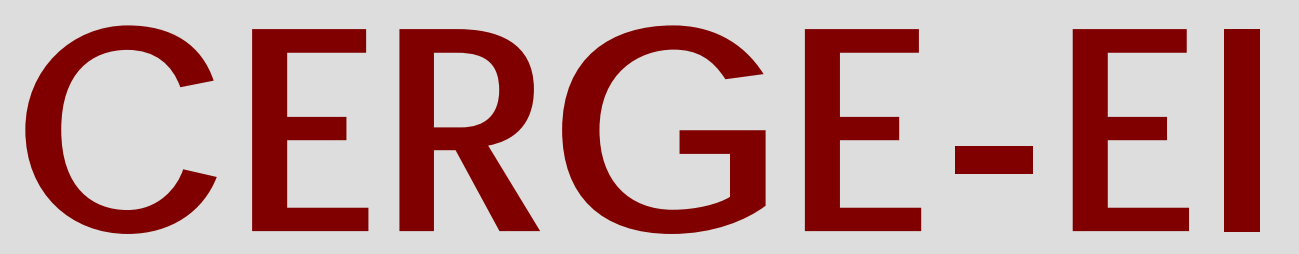

Charles University Centerfor Economic Research and Graduate Education Academy of Sciences of the Czech Republic Ec onomic s Institute 


\title{
Working Paper Series \\ 470 (ISSN 1211-3298)
}

\section{Suitability of Microfinance as an Investment Option}

\author{
Karel Janda \\ Barbora Svárovská
}

CERGE-EI

Prague, October 2012 
ISBN 978-80-7343-274-4 (Univerzita Karlova. Centrum pro ekonomický výzkum a doktorské studium)

ISBN 978-80-7344-266-8 (Národohospodářský ústav AV ČR, v.v.i.) 


\title{
Suitability of Microfinance as an Investment Option ${ }^{\#}$
}

\author{
Karel Janda* \\ $<$ Karel-Janda@seznam.cz>. \\ Barbora Svárovská ${ }^{* *}$ \\ <bsvarovska@gmail.com>.
}

\begin{abstract}
This paper investigates investment performance of the most commercially developed microfinance investment funds and it also includes a discussion of major economic characteristics of microfinance investments. When we analyze the relation between microfinance funds' returns and the performance of stock and fixed income markets in developed and emerging economies we find a slightly negative correlation. We show that returns of microfinance investment funds exceed the returns on the market portfolio. Together with reported near-to-zero beta estimates as a proxy for the systematic risk, this means that investment into microfinance investment vehicles may be recommended as a desirable addition to an investment portfolio.
\end{abstract}

\begin{abstract}
Abstrakt
Tento článek se zabývá investiční výkonností komerčně nerozvinutějších mikrofinančních investičních fondů a zahrnuje diskusi hlavních ekonomických charakteristik mikrofinančních investicí. Při analýze vztahu mezi výnosy mikrofinančních fondů a výnosy akciových trhů a trhů s fixními výnosy v rozvinutých a rozvíjejících se ekonomikách nacházíme lehce negativní korelaci. Ukazujeme, že výnos mikrofinančních fondů převyšuje výnos tržního portfolia. Spolu s téměř nulovými odhady beta koeficientů sloužícími jako zástupná proměnná pro systematické riziko naše výsledky znamenají, že mikrofinanční investice mohou být doporučeny jako žádoucí doplněk investičního portfolia.
\end{abstract}

Keywords: Microfinance, Investment, Funds, Risk, Return. JEL classification: G11, G21

\footnotetext{
\# The work on this paper was supported by the Czech Science Foundation (grants 403/10/1235 and 402/11/0948), by the Grant Agency of Charles University (grant 629112/2012) and by institutional support VSE IP100040. Karel Janda acknowledges research support provided during his long-term visits at University of California, Berkeley and Australian National University. The views expressed here are those of the authors and not necessarily those of our institutions. All remaining errors are solely our responsibility.

${ }^{*}$ Corresponding author. Faculty of Finance and Accounting, University of Economics, Prague and Institute of Economic Studies, Faculty of Social Sciences, Charles University, Prague and Affiliate Fellow at CERGE-EI.

CERGE-EI is a joint workplace of the Center for Economic Research and Graduate Education, Charles University, and the Economics Institute of Academy of Sciences of the Czech Republic.

${ }^{* *}$ Institute of Economic Studies, Faculty of Social Sciences, Charles University, Prague.
} 


\section{Introduction}

Since the early 1970s the modern microfinance movement has undergone a significant propagation throughout the developing world recently conquering the EU. In parallel to the geographic expansion, the spectrum of microfinance-related institutions has widened considerably, leading to the emergence of special investment vehicles that target microfinance institutions (MFIs) as an investment opportunity. The activity of microfinance institutions may be characterized by the provision of financial services (including small-sized loans, saving accounts or insurance products) to micro or small enterprises in developing and transition countries. The so-called microfinance investment vehicles (MIVs), which are foremost based in Western Europe or in the United States, serve as an intermediary between microfinance institutions and the final investor. They provide debt funding to microfinance institutions or directly acquire equity stakes in these lending institutions. The aim of this paper is to analyze the attractiveness of such microfinance investment vehicles for institutional or individual investors from developed countries in terms of funds' return qualities as well as their risk diversification potential.

The aim of this paper is to test two hypotheses connected to risk and return characteristics of specialized microfinance vehicles that directly or indirectly invest in microfinance institutions worldwide. Understanding what the risks of investing in microfinance are, what would the inclusion of microfinance assets in a broader portfolio result in, and how important returns on such investment (in addition to their social impact) are, may help a growing number of investment funds with the dual goal of bringing returns to investors and achieving social development to attract more funds. Due to increased funding in the form of debt or equity, microfinance institutions could expand and improve their services.

We will analyze the behavior of historical returns of microfinance investment funds specified in subsequent sections with respect to the movement of returns obtained from traditional investment strategies such as equity investment and investment in fixed income instruments. First, we will ask to what extent microfinance investment funds that are subject to this study are dependent on developed global markets as well as emerging markets. We may define out first hypothesis as:

- H1: Returns on investment in microfinance investment funds are not positively correlated with returns on a market portfolio.

In the case the first hypothesis is confirmed, we may argue that the addition of microfinance assets to a wider portfolio of assets (that is already well-diversified against a specific risk) could represent an attractive opportunity for an investor seeking portfolio diversification by decreasing the systematic risk of the overall portfolio.

Since risk management is only one part of an investor's field of interest, we will direct the second hypothesis towards microfinance funds' performance in comparison to market alternatives. In other words, we will examine whether the funds in question were, over the study period, able to generate average returns that would surpass or reach at least the same levels as returns on investment in a market portfolio. We define our second hypothesis as: 
- H2: Returns on investment in microfinance investment funds exceed the returns on a market portfolio.

We will present arguments that support our research hypotheses in the following section. To assess the prospects of investment in microfinance investment funds (both in terms of their risk profile and returns it generates), we will proxy the market portfolio by both developed and emerging markets indices in order to be able to capture the effect of different regional attributes. We will use fixed income indices in order to mimic the nature of investment in microfinance funds using primarily the money funds for acquisition of debt related instruments (see Table 2 for the instrument breakdown of studied MIVs). We will refer attributes of MIVs to the global and emerging markets stock indices because part of funds' capital can be invested in equity stakes of microfinance institutions too.

We will base our analyses on historical returns. The predictive power of any conclusion that we may reach is going to be limited by an assumption that we adopt, i.e. that historical returns may explain market trends. On the other hand, we find desirable that the period over which the study is conducted covers both bull and bear markets including rather the disturbing times after the financial crisis.

In the case both hypotheses be confirmed we may see the microfinance sector as a class of assets that is able to compete for the attention of both socially responsible investors but also commercially oriented institutional asset managers. In consequence, this move could bring more funding to the sector (and deeper down the sector towards the most impoverished microentrepreneurs), which would surely be a positive sign for developing countries (Svárovská, 2009).

\section{Related Studies ${ }^{1}$}

The following paragraphs present a survey of literature focusing on the evaluation of the microfinance sector from the perspective of potential investors. The main focus of the studies below is the attractiveness analysis of microfinance investment in terms of its systematic risk (i.e. dependence on domestic and/or world economy performance and financial markets) and return qualities.

Gonzalez (2007) conducted an empirical study on MFI assets quality as a proxy for the risk of MFI portfolios that focuses on its resilience to national macroeconomic shocks measured by changes in GNI (gross national income) per capita. His data set consists of data on four portfolio risk indicators (portfolio-at-risk measures (PaR 30 and PaR 90), ${ }^{2}$ loan-loss rate and the write-off ratio) related to 639 MFIs in 88 countries mainly for

\footnotetext{
${ }^{1}$ Survey of related studies is based either on papers explicitly referred to in the text or on literature survey already presented in Svárovská (2009) and Janda and Svárovská (2009a, 2009b, 2010).

${ }^{2} \mathrm{PaR} 30$ and PaR 90 relates to portfolio at risk (i.e. share of loans overdue) for more than 30 and 90 days respectively.
} 
the period 1999-2005. The analysis shows a statistically significant correlation of changes in GNI only with respect to the PaR 30 indicator, while for the remaining three risk indicators any significant impact of domestic macroeconomic events on portfolio quality has not been proved. This is very much in line with statistical evidence presented in Table 1. A strong resilience of microfinance institutions to the domestic economy has not, however, been confirmed by Ahlin et al. (2011) and Kraus and Walter (2009).

Ahlin et al. (2011) attempt to place microfinance institutions in national context examining whether and how an MFI's success is dependent on the macroeconomic and institutional structure and outcomes of the country where it is located. Based on a sample of 373 MFIs worldwide, they find that in general the country context (in terms of broader economy performance and macro-institutional environment) appears to be an important determinant of MFI performance. Ahlin et al. (2011) suggest that when growth is stronger MFIs are more likely to cover costs and that breaking even appears at least up to a point easier to do in richer countries. "Deeper financial sector is associated with lower operating costs, lower default, and lower interest rates, suggesting that broad financial competition does benefit microborrowers." On the other hand, they also find signs of rivalry between microfinance and industrial-led growth. "Workforce participation and manufacturing's share of GDP predict slower growth in outreach of MFIs. Also, MFIs don't always do better, and sometimes seem to do substantially worse when institutional environment is more developed" (Ahlin et al., 2011).

Kraus and Walter (2009) examine the correlation of microfinance institutions' performance to international as well as to respective local markets with the objective of finding out whether an addition of microfinance assets to portfolio represents an attractive opportunity for an investor seeking portfolio diversification. On the set of annual data of 325 leading MFIs covering the period 1998-2006, Kraus and Walter analyze the absolute market risk of the microfinance sector by regressing MFIs' key performance parameters (return on equity and profit margin used as profitability indicators, change in total assets and gross loan portfolio indicating changes in the value of assets, and the portfolio at risk indicator representing the loan portfolio quality) against S\&P 500, Morgan Stanley Capital International (MSCI) World and MSCI Emerging Markets equity indices as proxies for global market risk, and against a country's GDP as a domestic market risk proxy. In addition, they propose how to derive a relative market risk of investment in microfinance, i.e. within the emerging market investment opportunities, when exploring the relationship of the key MFIs' performance indicators 
to parameters of the same volume of emerging market commercial banks and businesses in general. In terms of absolute market risk interconnection, they found that MFIs are not correlated with global capital markets, whereas for the domestic economy correlation they found some significant results. Compared to benchmark institutions, MFIs appeared to be significantly less correlated to global markets than other emerging market financial institutions and businesses, which were examined. Kraus and Walter concluded that "MFIs may have useful diversification value for international portfolio investors able to diversify away from country risk exposures. For emerging market domestic investors, who may have this ability to a much more limited extent, domestic microfinance investments do not seem to provide significant portfolio diversification advantages" (Kraus and Walter, 2009).

Galema et al. (2011) investigate whether the inclusion of microfinance funds in a portfolio of risky international assets (equity and bond investment) is beneficial and yields diversification gains. The analysis is based on the mean-variance spanning test that relies on the assumption that investors' investment decisions are solely made on the basis of the mean-variance properties of assets. As a proxy for MFI market returns they use annual returns on equity (ROE) and returns on assets (ROA) of MFI's that report their figures to the MIX Market database. ${ }^{3}$ MFI's returns covering the period from 1997 to 2007 are analyzed against the MSCI World and MSCI Emerging Markets equity indices as in case of Kraus and Walter (2009), while J.P. Morgan Global Broad and J.P. Morgan Emerging Markets Global Composite indexes were used as benchmarks for the fixed income market. The analysis suggests that, in general, microfinance may be attractive for investors seeking a better risk-return profile and, more specifically, that microfinance investment may be valuable as an addition to the debt part of a globally diversified portfolio. In addition, MFIs were also examined from the regional point of view where investment in MFIs from Latin America yields the most efficient portfolios.

Koivulehto (2007) aims to find out if microloans generate sufficient returns when confronted with a competitive environment, where capital owners can choose between different investment opportunities (e.g. corporate or government bonds). The risk of a loan portfolio of 24 MFIs in the sample is proxied by the proportion of loans that have to be written off during each period. The write-off ratio is used to describe the likelihood of default for each MFI in the sample. MFIs are subsequently allocated

\footnotetext{
${ }^{3}$ See http://www.mixmarket.org.
} 
in different risk categories and returns are directly compared with yields on commercial bonds that fall within the same risk category in order to acquire differences in risk-adjusted returns. Koivulehto (2007) finds substantial regional differences in microcredit profitability: "The sample MFIs located in the Middle East and North Africa as well as in Sub-Saharan Africa performed worst (yields were 34.66 and 19.27 percentage points lower than demanded, respectively), while those operating in East Asia and the Pacific region could almost reach investors demands ( -2.78 percentage points). By contrast, microcredit operations of MFIs located in Eastern Europe and Central Asia as well as in Latin America outperformed bond markets by 0.47 and 5.20 percentage points respectively" (Koivulehto, 2007). In total credit operations of 24 MFIs observed between 1997 and 2005 generated a return that was 7.41 percentage points lower than investors would have expected with a variance of returns of about 30 percentage points.

Janda and Svárovská (2010) investigate a monthly performance of 5 commercial microfinance investment funds (MIVs) and their currency sub-funds (USD, EUR and CHF) from January 31, 2006 until March 31, 2009. The examined funds have recorded lower total risk than global stocks and bonds (measured by four benchmark indices) with moderate but stable returns. The analysis revealed that investment in microfinance investment funds represents an attractive opportunity for portfolio diversification as this asset class does not show any positive correlation with global or emerging capital markets. At the same time, it provides adequate risk-adjusted returns and may therefore be attractive not only for investors with a particular interest in the socially responsible aspect of investment into microfinance (Janda and Svárovská, 2010).

While in the previous study we did not include all the existing funds due to the short length of the series, this study aims to encompass as many commercial microfinance investment funds as possible (no matter the length of the time series) to provide more tangible financial implications of the investment in commercially-oriented MIVs. We overcome the difficulty of short data by unbalanced panel data analysis as well as by the construction of a theoretical microfinance portfolio described in detail in section 5 . In addition, we examine Euro and U.S. dollar denominated funds separately and adjust their returns by risk-free rates in respective currencies to avoid possible bias caused by the volatility of the EUR/USD exchange rate. Longer data series used (from January 2006 until September 2010) cover an interesting period with respect to the recent financial crisis as well as the economic recession that followed and will allow us to evaluate the risk and return qualities of microfinance funds with regard to this aspect. 
Inclusion of more investment funds, longer time series, and the use of a cross-sectional regression approach instead of separate time series analyses as in Janda and Svárovská (2010), should contribute to more robust results.

\section{Microfinance and Microfinance Investment Funds ${ }^{4}$}

There are several main reasons why in some parts of the developing world people lack the access to credit or other financial services. These are the lack of collateral, credit history or a statement of income that MFIs could rely on and, more fundamentally, the lack of an identification card. In addition, the geographical location of dwellings of low-income entrepreneurs may not enable a development of traditional banking systems at acceptable costs. The role of MFIs is important as microfinance institutions' customers are in vast majority low-income microentrepreneurs who otherwise would not be served by commercial banks because they are considered high risk. ${ }^{5}$ They seek credit and others services in order to set up or manage their own business that may range from making handcrafts, tortilla-making business to running small shops (Svárovská, 2009).

Microfinance is perceived to be a tool for economic development and poverty reduction. Cull et al. (2009) see microfinance as a concept that centers on self-help rather than direct income redistribution. Promotion of self-employment and gender empowerment (through an important focus on female customers) is also an important aspect related to development. In addition, microloans are especially important in helping people with self-discipline problems who lack suitable saving devices to accumulate capital (Bauer et al., 2008) and with respect to their ability to expand households' abilities to cope with emergencies, manage cash flows and invest for the future (Cull et al., 2009).

High administrative costs of this kind of banking, including provisions for possible losses from unpaid loans, geographical dispersion of clients etc., are compensated for

\footnotetext{
${ }^{4}$ The description of microfinance and microfinance funds is either based on microfinance related literature explicitly referred to in the text or on description already presented in Svárovská (2009) and Janda and Svárovská (2009a, 2009b, 2010).

${ }^{5}$ The financial sector in developing countries could be characterized by the coexistence of formal financial institutions (commercial banks, development banks and saving banks that, however, fail to serve the most impoverished social classes) and of an important informal sector where we would include groups of individuals organized in saving associations (such as ROSCAs - rotating savings and credit associations whose members agree to regularly contribute money to a common "pot" that is allocated to one member of the group each period (Armendáriz de Aghion and Morduch, 2005)) or practices of individual moneylenders (loan-sharks) charging interest rate levels highly above the local formal sector rates. On the frontier of both sectors we may locate another form of group-based banking - the credit unions or credit cooperatives that could be classified as a part of the semi-formal financial sector as they are formally registered under the law but in general are subject to different (less prudent) regulations than traditional commercial banks (Svárovská, 2009).
} 
by high rates of interest. Gonzalez et al. (2009) note that the average interest yield (weighted by loan portfolio) for MFIs reporting to MIX Market database in 2006 was 28.1 percent for sustainable MFIs, compared with 20.5 percent for unsustainable ones. ${ }^{6}$ On the other hand, interest rates are commonly substantially lower than those of local moneylenders who routinely charge interest rates of over 100 percent p.a. (Cull et al., 2009).

The modern microfinance movement emerged in the early 1970s based on two independent pioneering initiatives in Latin America and Bangladesh. Microfinance has become most well-known, however, after Bangladeshi professor Muhammad Yunus and the Grameen Bank he set up, were jointly awarded the Nobel Peace Prize for "their efforts to create economic and social development from below. Lasting peace can not be achieved unless large population groups find ways in which to break out of poverty. Microcredit is one such means. Development from below also serves to advance democracy and human rights." (2006 Prize Laureates: http://nobelpeaceprize.org). Grameen was established in 1983 in response to a successful university class project that Yunus initiated in 1976 firstly lending from his own pocket to poor villagers who before borrowed money from local moneylenders at rates as high as $10 \%$ a week (History of Grameen Bank: http://www.grameen-info.org).

Most microfinance institutions, especially in their early years, were originally founded as nongovernmental (i.e. non-profit and non-regulated) organizations relying on donors and international development organizations. The current microfinance sector is, however, characterized by the commercialization of microfinance and transformation of originally NGO-managed institutions into for-profit institutions integrated within the formal financial system (see Christen and Drake (2002), Lauer (2008) and Ledgerwood and White (2006) for details).

In addition to retained profits and deposit collection, MFIs' operation and expansion of activities also often require external forms of funding. These concern private capital placements, debt financing (including direct loans to MFIs, bond issuance and all debt-related instruments such as the collateralized debt obligations). The current trend of transformation and commercialization results in an increasing number of more

\footnotetext{
${ }^{6}$ Grameen Foundation reports that MFIs' interest rates can range from 18 to 60 percent, depending on the conditions in each MFI's service area (Grameen Foundation: http://www.grameenfoundation.org). Among the extreme cases we could include interest rates paid by customers of well-known Mexican Compartamos's bank at the time of its IPO of 94 percent per year on (once 15 percent value added taxes were included) (Cull et al., 2009).
} 
commercially viable MFIs that are likely to attract foreign investors. According to Forster and Reille (2008), approximately half of all investment in microfinance from developed countries is channeled to MFIs through specialized financial intermediaries that are collectively referred to as microfinance investment vehicles (MIVs). MIVs propose a collective investment in a large spectrum of microfinance institutions. Figure 1 reflects recent development in the sector of microfinance investment funds. ${ }^{7}$ Currently, there are 78 MIVs of different legal structures worldwide (as of December 31, 2009; MicroRate, 2010) that have under management assets worth more than USD 6 billion.

- insert Figure 1 here -

\section{Economic Links between Microcredit Features, Risk Taking and its Return Perspectives}

In the paragraphs below we group several issues that are important in assessing the risk and return profile of microfinance funds or more precisely of the underlying assets of these funds, i.e. loans to microfinance institutions or equity participations in such institutions. We will aim to provide a balanced discussion of opportunities and threads or currently perceived shortages in the microfinance sector. Different aspects discussed in the section attempt to provide arguments that would support the two previously stated hypotheses (of excess returns and non-correlation to the world markets).

\section{Return Perspectives}

The success of certain commercial MFIs ${ }^{8}$ indicates that provision of loans and other financial services to poor clients can be a very attractive business. According to Byström (2008), there are arbitrage possibilities in the banking services sector in developing countries that remain to be exploited. This is due to high interest rates that low-income entrepreneurs pay to money lenders and it still pays them off. Economic theory suggests that people without any start-up capital value capital more as they can

\footnotetext{
${ }^{7}$ The term of microfinance "fund" is commonly used instead of investment vehicle despite the fact that in the legal sense many of them are not necessarily investment funds in the proper sense of the term as it is widely understood in financial markets (e.g. mutual funds). (Svárovská, 2009). We shall use the terms "microfinance investment vehicles (MIVs)" and "funds" interchangeably if not specified otherwise.

${ }^{8}$ The most know microfinance bank is already mentioned Grameen Bank. As the most commercially developed MFIs we may perceive institutions that were introduced on local stock markets (e.g. Mexican Compartamos Banco, Bank Rakyat Indonesia, Equity Bank in Kenya, or a recent IPO of Indian SKS Microfinance).
} 
earn relatively more on it. They are, therefore, also able to pay higher interest rates, which contributes to higher returns for financial providers. This is a consequence of the principle of diminishing marginal returns to capital derived from the assumption of the concavity of the production function suggesting that low-income entrepreneurs should earn higher returns on additional capital than rich entrepreneurs that have already made some investments (Armendáriz de Aghion and Morduch, 2005). Microfinance institutions may for the reasons of capital scarcity charge higher interest rates than what would be common in Western countries. Although interest rates charged by MFI are relatively high, they generally remain lower than rates of the so-called loan sharks.

\section{Potential Demand for and Supply of Microfinance Services}

In the financial services sector in developing countries the supply does not meet the demand. ${ }^{9}$ Estimates of the supply-demand gap for microfinance services vary by source, but remain very high in all cases suggesting that capital markets could play an important role in filling the gap. Deutsche Bank (2007), for example, estimates total sector demand to be about 1 billion microborrowers and the gap in financing for the microfinance industry (incl. debt, subordinated debt, equity, deposits, and guarantees) to be worth USD 250 billion, whereas Christen et al. (2004) estimate the target market to be 3 billion potential MFI customers while the number of active clients already served by the alternative financial institutions, including microfinance institutions, was estimated at 500 million as of 2004. This would result in the rough estimate of the global supply-demand gap of 1 to 2.5 billion of unserved low-income clients.

Unmet demand for loans and deposit services provides an encouragement for the future development of microfinance institutions. Assuming that additional capital to expand is available for lending institutions and that they are technically apt to reach new clients, high demand should lead to the growth of microfinance portfolios. This will contribute to better effectiveness of MFIs in terms of costs per dollar earned on interest, which is a good sign for prospective investors in MFIs or microfinance funds.

The most discouraging feature of investing in microfinance is the lack

\footnotetext{
${ }^{9}$ The World Bank reports that there is currently only 26 percent of the world's population that has access to formal financial services (World Bank: http://www.worldbank.org). According to the recent survey of financial regulators carried out by the World Bank's arm CGAP (Consultative Group to Assist the Poor), there are nearly four times more loans per adult in developed countries than in developing countries (0.82 bank loans to individual per adult in developed countries versus 0.22 loans per adult in developing countries). In terms of deposit accounts developing countries have three times less deposits per person than it is the case in developed countries ( 1.77 bank deposits per adult in developed countries compared to 0.52 deposit accounts per adult in developing countries). Data are from Financial Access 2009 survey of financial regulators, usually central banks, in 139 countries covering more than 94 percent of the world's population and nearly 98 percent of world GDP. (CGAP: http://www.cgap.org).
} 
of information about the sector and the fact that investors do not perceive microfinance assets as an independent asset class. To persuade traditional investors seeking more than a social impact to get engaged in the microfinance sector, global credit rating of MFIs and microfinance investment vehicles carried out by independent rating bodies as well as reliable performance indicators would be needed. A lot of work in these matters has already been done by Microfinance Information Exchange, Inc., a non-profit organization that seeks to gather and provide objective data and analysis on microfinance providers, and its web-based microfinance information platform MIX Market. Other important actors in the field of microfinance reporting and evaluations are MicroRate, a rating agency dedicated to the evaluation of microfinance institutions and microfinance investment vehicles formally approved by the World Bank; and Luxembourg Fund Labelling Agency (LuxFLAG) which awards a recognizable label to eligible microfinance investment vehicles reassuring investors that MIVs actually invest, directly or indirectly, in the microfinance sector.

Better awareness about microfinance investment options could be achieved as time goes by and as more institutional and private investors increase their shares in microfinance assets (e.g. pension and health insurance funds represent high hopes for microfinance given the volume of funds they manage). Microfinance is also attractive for a fast-growing segment of Socially Responsible Investors (SRIs) seeking investment opportunities that offer positive financial returns while pursuing certain social or environmental missions. ${ }^{10}$ Due to the fact that investment in microfinance strengthens development, stressing this feature may also be a good marketing tool for some institutions.

\section{Microfinance Specific Risks}

Investors may perceive that there are several risks associated with microfinance investment. The specificity of microfinance activities - provision of loans in developing countries and without the reliance on collateral - may raise concerns of investors with respect to the specific risk of such assets. Among the risk factors we find institution-specific, sector-specific as well as country-specific risks. Such risks include increased share of non-performing loans, bad corporate governance, inefficiencies inside the lending institution, impossibility of legal enforcement of investors' rights etc. These risk factors may jeopardize the ability of MFIs to meet their obligations in terms of paying interests on loans or earning returns to their shareholders.

The institution-specific risk can be diversified by investment through specialized

${ }^{10}$ Over $10 \%$ of assets under professional management in the U.S. was in 2007 involved in socially responsible investing (i.e. USD 2.7 trillion out of total volume of assets under management of 25.1 trillion) (Socially Responsible Investing Facts: http://www.socialinvest.org). 
microfinance funds. MIV's asset managers diversify their investment across various developing countries and MFIs that in turn provide loans to a wide range of clients active in different sectors from trade to agriculture. The country risk is, on the other hand, present also when investing in institutions other than banking institutions in emerging markets, and investors simply expect risk premium in terms of yield achieved. The country risk includes unclearly defined institutions and one country's legal environment, unstable macroeconomic conditions, specific political uncertainties in each country or difficulties related to natural catastrophes, and epidemics or wars in respective regions.

Predominant from the investors' perspective is the sector-specific risk. In this respect the most important microfinance characteristic is the fact that loans are provided without collateral. Microfinance institutions have developed diverse risk-management techniques to cope with moral hazard and adverse selection. Even though over the recent years MFIs reported high repayment rates on their loans, the question that remains to be answered is the impact of the global recession on borrowers' repayment behavior. Dependence on macroeconomic cycles is discussed further below. The fact that a vast majority of shares or debt instruments issued by MFIs are not publicly traded brings a certain level of liquidity risk. The locus of MFIs' operations in developing countries with often volatile currencies that might not be easily hedged results in foreign currency exchange risks for investors, MFIs or borrowers.

\section{Moral Hazard and Adverse Selection}

The provision of loans involves many risks including moral hazard and adverse selection resulting from market imperfections. ${ }^{11}$ Credit markets all over the world are governed by information asymmetries and lending institutions are not able to differentiate between safe and risky entrepreneurs. Collateral requirement is probably the most efficient way to address the resulting problems of adverse selection and moral hazard (i.e. to limit the share of non-performing or overdue loans). Sound credit history and income confirmations also aim to better cope with these market imperfections in developed countries.

The major distinguishing feature of microfinance compared to credit provision in developed countries is the provision of loans without the requirement of collateral. Innovative features of microfinance intended to diminish the credit risk and to ensure a smooth repayment of loans include the provision of small-size loans with short maturities (as short as three months), flexible repayment schedules, and high frequency of installments. These installments could be weekly or bi-weekly but there are also cases when credit is repaid daily (usually when borrowers are for example merchants that buy and sell products on a daily basis) (Svárovská, 2009). A focus on female customers who, in general, have higher repayment morale provides the potential to obtain high repayment

\footnotetext{
${ }^{11}$ The problem of adverse selection and moral hazard on credit market is described for example in Stiglitz, J.E. \& Weiss, A. (1981). Credit Rationing in Markets with Imperfect Information. American Economic Review, 71 (3): 393-410.
} 
rates. A frequent personal presence of loan officers in borrower communities who assess borrowers' financial capacities is also beneficial.

The group lending concept (i.e. conditioning of new loans on full repayment of old ones by the whole group), is, however, probably the most critical innovation of microfinance and it is often argued that it contributes significantly to low loan delinquency figures. The group liability feature of microcredit takes advantage of borrowers' close ties within their community creating self-monitoring of the group and a "peer pressure" to repay (Armendáriz de Aghion and Morduch, 2005). It also allows group members to bail each other out when one of the members has problems with paying back.

Although the above mentioned features of microfinance have been heralded for efficiently coping with market imperfections, we also find in the microfinance literature powerful reasons why certain features of microcredit, especially the group lending component, may not have the above described effects. Giné and Karlan (2009) find no change in repayment rates when the group-liability component is removed and borrowers switch to individual borrowing. Moreover, instead of reducing moral hazard group liability may induce participants to take on more risk, or may induce all members not to repay in a situation when one group member is in trouble (Giné et al., 2010). This could be particularly relevant if worsening economic conditions hit some members of the group. This would result in higher risk of contagion to other members compared to standard individual-level lending. According to Cassar and Wydick (2010), the success of these risk-management techniques depends on the social context and is susceptible to differences in cultural environment and religions.

\section{Impact of Macroeconomic Cycles on Repayment Behavior}

The success of the microfinance movement is demonstrated by unexpectedly low default rates on the loans provided that can easily keep up with Western countries' credit markets. Nevertheless, some risks are still present in this matter connected to unexpected unfeasible situations of microclients. Despite the fact that microloan is an investment loan and not a consumer one and is not meant to cover daily financial needs, poor households operating on tight margins often do not distinguish much in this respect and some consumption lending is inevitable. In particular, food price fluctuation (e.g. due to global or regional harvest crises) along with a decline in remittances flows (remittances represent a substantial portion of some developing countries' incomes) due to unfeasible economic conditions in countries where visiting workers receive their wages, could impair one's living conditions to such an extent that she/he would use loans mainly for consumption. A change in the aim of a loan from income generation to consumption endangers the repayment discipline and the economic basis of the microcredit in general.

When the overall economic conditions (in terms of national income) in a particular country deteriorate, we may be able to observe a mixture of resulting tendencies in the repayment behavior of microborrowers as well as in the total demand for microcredits. These should have direct repercussions on the overall profitability 
of MFIs. Ahlin et al. (2011) suggest two antagonistic consequences of economic growth on the microsector with respect to its demand for microloans. "A growing economy may raise households' current or expected future incomes to the degree that they are willing to take on more risk by investing capital in a business venture. Ingredients of growth - increasing physical and human capital, better institutions, technological advancement - may also make microentrepreneurship more profitable" (Ahlin et al., 2011). On the other hand, Ahlin et al. remind us that microfinance may depend on a vibrant informal economy that tends to develop more in times of worse overall economic conditions and its institutions. A related issue is the decreasing number of wage-earning opportunities in a period of decelerating economic growth and resulting increased self-employment. While the latter suggests that microfinance institutions may gain more borrowers in bad times, nothing is said about their ability to promptly repay loans in such a situation.

Therefore, we focus on the possible implications of economic slowdown on the demand for the products of microborrowers. It might be that microborrowers operate in small segmented local markets. Very often the core of microcredit clients' business is in the sector of manufacturing of, and trade with, necessary goods or services that are known to be income inelastic in their demand. When the living standards decrease purchased quantities of these goods and services decrease only to a lesser extent. A deceleration of growth may induce consumers to move away from imports or higher quality goods towards products produced by microenterprises (Ahlin et al., 2011). In addition, due to the small size and low capital intensity of their business activities poorer microentrepreneurs are most likely to be able to adapt their business when costs rise or demand dries up. For all the reasons above, we may therefore assume that income-generating economic activities of microentrepreneurs are resilient to macroeconomic conditions and act outside of or against the economic cycle.

Looking into statistics, we find that the ratio of loans for which borrowers were late with repayment for more than 30 days (portfolio at risk - PaR 30) ${ }^{12}$ increased from 2005 to 2008 according to a survey of existing microfinance institutions worldwide carried out annually by Microfinance Information Exchange (see Table 1). An increased share of portfolio at risk (3.1\% in 2008), however, did not have any repercussions on the overall value of written-off loans in respective years with median loan loss rates reaching up to 1 percent of average gross loan portfolio over the above mentioned time span. As a point of reference, the general rule of thumb in microcredit is that annual loan losses of more than about 5 percent tend to become unsustainable (Gonzalez et al., 2009). The overall MFI benchmarks report for 2009 (incl. loan loss rates), however, was not published at the date of writing this dissertation and only partial results for the portfolio-at-risk measure (PaR 30) were known. According to Kneiding et al. (2010), during the first five months of 2009 MFIs' PaR 30 ratio jumped to a median of $4.7 \%$ but stabilized since June 2009 at the level of $4 \%$. Nevertheless, this data does not allow us to draw any preliminary conclusions on the impact of the world financial crisis and subsequent recession worldwide on microcredit default rates. We may consider that there would be at least

\footnotetext{
${ }^{12}$ See note to Table 1 for exact definition of PaR 30 ratio as well as other credit risk measures.
} 
a slight delay in the reaction of emerging markets, therefore the positive result of the overall figure for 2008 is not surprising.

- insert Table 1 here -

While there might be more and sometimes opposite theoretical implications of the change in macroeconomic conditions on microborrowers interest in loans and their ability to repay (and therefore on lending institutions profitability), in general it is believed that changes in the economic cycle of the domestic economy and/or abroad do not have a significant impact on the business activities of such microenterprises. The results of MFIs' profitability and connected loan loss rates for the next few years should give investors a better insight into microfinance performance. Since macroeconomic development and stock and bond market performance are commonly interconnected we rely on the previously stated assumption to back up our first hypothesis of non-correlation of microfinance repayment behavior and financial markets performance.

\section{Liquidity and Foreign Exchange Rate Risk}

Direct investment in equity or debt instruments issued by microfinance institutions may raise investors' concerns with respect to the related liquidity risk. MFIs are not publicly listed (with a few exceptions) and equity investment occurs through privately placed assets that are not liquid in the short term. In addition, there are often no local secondary markets for the trading of debt instruments issued by MFIs. Indirect investment through specialized microfinance funds enables investors to diversify the specific risk of a particular MFI and to partly avoid the liquidity risk. For MIVs that were set up as open-ended funds, it holds that they offer redemption rights entitling investors to ask for a redemption of their units and a cash payment for the investment any time during the course of the investment even though some time restrictions may apply (for example for responsAbility Global Microfinance Fund redemption of units is possible at the end of each calendar quarter with a notification of 45 calendar days in advance (responsAbility Global Microfinance Fund's monthly report September 2010: http://www.responsability.com). Funds are obliged to keep part of their assets in cash and liquid assets for this reason. Due to the relative illiquidity of MIV's underlying assets, funds' portfolio valuation on a daily basis typical for traditional equity or bond investment funds is impossible, and most funds revaluate portfolios monthly (see Table 2 for this characteristic for the selection of funds).

Foreign exchange rate risk also represents an issue of concern. When providing debt funding to an MFI, three parties can take on the currency risk: the investment fund if it lends to MFIs in local currencies, the MFI if it borrows in U.S. dollar or Euro and lends to its clients in local currency, or the microborrower if she/he borrows in hard currency to invest in local currency-generating activity (which is the less common alternative). For investors in most of the commercially oriented microfinance funds, this is not an immediate risk because they are denominated in hard currencies (USD, 
EUR, CHF) and lend in those currencies. In fact, according to de Sousa-Shields and Frankiewicz (2004) over $85 \%$ of loans to microfinance institutions and investments in MFIs are in hard currency. The risk and cost of exchange rate fluctuations is therefore often borne by MFIs (hedging strategies are costly and may be hard to implement), which may have repercussions for their profitability.

\section{Estimation Methodology}

\section{Definition of Performance Measures}

In order to examine whether microfinance investment funds have (or do not have) a portfolio diversification value for an investor, we need to assess their risk within a broader portfolio and analyze the fund's correlation to chosen benchmarks. Towards this aim, we will assess the portfolio beta in the tradition of the Sharpe (1964) and Lintner (1965) capital asset pricing model (CAPM) as specified in equation 1, regressing the risk-free rate adjusted returns of studied microfinance investment funds (hereinafter also "excess returns" or "adjusted returns") against four selected market portfolios (world indices).

$r_{i t}-r_{f t}=\alpha_{i}+\beta_{i}\left(r_{M t}-r_{f t}\right)+\varepsilon_{t}$

where $r_{i t}$ and $r_{M t}$ are returns of a microfinance fund or portfolio $i$ and of a market portfolio $M$ respectively, $r_{f t}$ is yield on a risk-free asset in time $t$ and $\varepsilon_{t}$ is the error term for time $t$.

We will draw our conclusions with respect to the studied funds' risk and return features upon estimated values of regression coefficients $\alpha$ (Jensen's alpha) $\beta$ and the value of model's R-squared.

\section{Use of Cross-sectional and Weighted Portfolio Approach}

We will approach the estimation of microfinance portfolio beta, Jensen's alpha and resulting R-squared (according to equation 1) in two different ways that we will subsequently compare with each other. Similar results of both methods should contribute to a greater robustness in our results.

Firstly, we will carry out a cross-sectional regression of adjusted returns of individual funds on adjusted market returns taking advantage of unbalanced panel 
methods. By the use of unbalanced panel approach we avoid the problem of different times of funds' introduction on the market as well as of disappearance of several funds up to this day. ${ }^{13}$ As pointed out by Brown et al. (1992), leaving out dead funds leads to an upward bias of relative performance measures as poor performers are liquidated or merged into other funds. Ferson and Schadt (1996) suggest that the presence of survivorship bias shifts the distribution of Jensen's alphas to the right leading to, on average, higher systematic risk-adjusted performance results. The inclusion of dead funds enables us to avoid such survivorship bias. In addition, the panel structure of our study allows tracking the development of individual MFIs' returns over time and helps to prevent flaws caused by period-specific exceptional events for individual funds.

The second approach we choose to apply in estimation of equation 1 is the use of equally-weighted portfolio of studied microfinance investment funds (hereinafter also "EUR or USD microfinance portfolio"). We will constitute such a theoretical portfolio and regress its excess returns against excess returns of market indices. Due to the different length of MIV's monthly return series, the portfolio is rebalanced each time a new fund was introduced and/or some fund disappeared so that each fund's share in the portfolio is the same. In order to encompass as many microfinance funds as possible and to carry out an analysis of risk and return characteristics over the long-run (including times of stock exchange bear and bull market), we assume such reinvestment strategies (i.e. selling of shares in disappearing funds to buy remaining MIVs and selling of some shares of present-state funds to buy shares in newly launched microfinance funds).

\section{Data}

\section{Microfinance Funds' Data}

In order to find out more about the attractiveness of microfinance for investors, we study monthly returns of 21 selected open-end microfinance investment funds from January 2006 to September 2010. Fifteen funds are denoted in Euro, the remaining 6 are USD denominated funds. The fund's performance data (in terms of historical net asset values per share - hereinafter "NAV") were acquired using Bloomberg. Additional data on microfinance investment funds were collected by hand using funds' prospectuses,

\footnotetext{
${ }^{13}$ See Table 2 for the exact dates of market introduction of each fund in the study.
} 
monthly and annual reports and websites.

The microfinance investment vehicles universe comprehends according to a survey carried out by MicroRate 88 MIVs of different investment structures worldwide (as of December 31, 2009). ${ }^{14}$ Therefore, we cannot claim the chosen sample of funds is a representative of the entire universe of investment vehicles in microfinance, nor of all MIVs of the same investment structure. Rather, funds were selected based on three criteria:

- Availability and quality of data. - We selected funds whose NAVs are either publicly available or could be accessed by Bloomberg. An additional criterion was the reporting of NAVs on at least a monthly basis.

- Commercial funds. - In terms of the fund's commercial orientation, most current microfinance literature distinguishes three categories of funds: (1) Commercial MIVs taking the form of investment funds or investment companies providing loans at market conditions and seeking financial returns. These funds target financially sustainable MFIs and invest mainly in debt instruments; (2) Quasi-commercial/ dual-objective funds that strive to balance development objectives with modest financial returns while maintaining their borrowing conditions below or close to the market. Their target group may include microfinance institutions that are close to becoming sustainable. The share of equity holdings in MFIs is in general greater than in the first group of funds; (3) Development funds that provide funds at subsidized conditions and where main contributors are NGOs, foundations or charity organizations who seek social returns in the first place. (Based on Goodman, 2007).

Microfinance investment vehicles that are the subject of this study fall within the group of commercial MIVs which focus mainly on financial objectives, while their social and development contribution is a sort of a value added that sets these funds apart from traditional mutual funds. (Svárovská, 2009).

- Structure of investment vehicle. - We include solely funds that are structured as open-end mutual funds, or its parallels depending on the country of origin, offering redemption rights at any time during the course of investment.

From the pool of existing MIVs it appears that the sample includes the most developed funds with transparent portfolio structure inherent to developed financial markets and clearly defined financial and social objectives. Those are, in our opinion,

\footnotetext{
${ }^{14}$ MicroRate (2010)
} 
funds that commercially oriented investors not familiar with the microfinance sector may consider.

In calculation of monthly returns, net asset values of funds per share were used. The use of monthly data is justified by the fact that for most of the funds the net asset values are calculated on a fixed valuation day once or twice a month (see Table 2 for details). We focus on market returns (in terms of change in NAV per share, which is the price investors pay for a share and are paid when redeeming fund's shares) that are the actual investor's returns compared to previous papers on investment in microfinance looking at annual book values of MFI's assets and other performance ratios based on MFIs' annual financial reports (see section 1 for literature survey). Another advantage of evaluating directly microfinance investment funds is the use of monthly net asset values, which allows us to examine the impacts of the global economic recession triggered by the financial crisis after the fall of Lehman Brothers in September 2008.

All funds' returns are reinvested (MIVs' return did not have to be in any way adjusted). All returns are net of management expenses and administrative fees but disregard subscription and exit fees and are before taxes. We use in our analysis basic return formula (equation 2) as well as natural log return formula (equation 3) to minimize the effect of possible outlier observations on returns. ${ }^{15}$

$$
\begin{aligned}
& r_{t}=\left(X_{t}-X_{t-1}\right) / X_{t-1} \\
& r_{t}^{\ln }=\ln \left(X_{t} / X_{t-1}\right)
\end{aligned}
$$

where $X_{t}$ refers either to the net asset value of a microfinance fund in time $t$ or to the index level of a given market benchmark in time $t$.

\section{Performance Benchmarks and the Risk-free Rate}

In the performance evaluation, our aim is to compare the returns on microfinance investment funds with the returns on certain benchmarks that might be investors' main alternative to microfinance engagement. We will use multiple indices as proxies for the market risk in order to account for multiple investment alternatives of potential investors and to augment the robustness of our results. We chose to include both stock

\footnotetext{
${ }^{15}$ A graphical analysis has not shown a presence of outliers in case of returns of microfinance investment funds. Nevertheless the use of natural log return formula is justified especially for the benchmark indices' returns that could be prone to outliers.
} 
indices as well as fixed income benchmarks as the majority of funds in the studied portfolio may provide loans and invest in debt instruments as well as these funds may acquire equity stakes in MFIs. The use of equity indices is specifically justified by the fact that both stocks and microfinance assets may address the same type of investors, i.e. investors who are not risk-averse.

Microfinance funds in the sample differ in their legal domicile and may target investors from different European countries. In many cases funds are located in Luxembourg or Switzerland (due to tax purposes, favorable legal and regulatory environment as well as high concentration of specialized service providers) ${ }^{16}$ but they target clients from other EU countries, most often France, Belgium, the Netherlands or the UK. ${ }^{17}$ We reflect the fact that potential investors originate from different European countries with well-developed financial markets and thus require a yield that could be achieved on their local markets by the choice of broader European and world indices instead of choosing purely Luxembourgish or Swiss equity and fixed income benchmarks as proxies for the market portfolio. The nature of the underlying investment of microfinance funds in the sample, i.e. provision of loans to and investment in equity stakes of microfinance institutions gathered worldwide, but most frequently in Latin America, Eastern Europe and Asia (see Table 2 for the geographic breakdown of underlying investment projects of MIVs in the studied sample), is underlined by the addition of emerging markets proxies. The regional focus simulates the additional market risk of such investment which is related to political and economic issues as well as currency risks.

Global bond markets are proxied by Markit iBoxx EUR Liquid Corporates Index reflecting yields on Euro denominated highly liquid corporate bonds. In order to examine microfinance funds' performance relative to the emerging fixed income markets, we will work with the J.P. Morgan Emerging Market Bond Index Plus (J.P. Morgan EMBI+) which is intended to replicate the total returns of traded external debt instruments

\footnotetext{
${ }^{16}$ Fund managers choose Luxembourg as domiciles for their funds mainly because of favorable tax environment. Funds set up as a Part II Fund (all in our sample) benefit in Luxembourg from the exemption from income tax, net wealth tax, withholding tax on dividends and capital gains (except for cases when EU Savings Directive applies) as well as no VAT is paid on management fees. Trend of concentration of microfinance funds in Luxembourg is likely to continue as the Luxembourg Government decided in 2010 to exempt microfinance investment funds from the only tax they were subject to - the subscription tax of either $0.01 \%$ or $0.05 \%$ of NAV depending on instruments a fund invests in - in order to encourage the development of this fund type in Luxembourg (Association of the Luxembourg Fund Industry, 2010).

${ }^{17}$ Information about the target investors' nationalities of microfinance funds in the sample are based either on information cited on fund's websites or such assumptions are derived from information given in funds' prospectuses about the eligible countries where shares of given funds may be sold (i.e. the offering of shares of certain funds may be restricted in certain jurisdictions).
} 
in the emerging markets. To describe the stock market we consider the Morgan Stanley Capital International (MSCI) World Index, which is designed to measure the equity market performance of developed markets (Index definitions: http://www.mscibarra.com). In addition to looking at the risk and return characteristics of MIVs in the light of global stock markets, we also compare them to emerging markets securities by regressing fund's returns against MSCI Emerging Markets Index (MSCI EM). The MSCI EM Index covers regions that are often represented in portfolios of studied microfinance funds (the index includes countries such as India and countries of Southeast Asia, followed by Mexico and South American countries as Brazil, Chile, Colombia or Peru) (Index definitions: http://www.mscibarra.com). Returns on benchmark indices are calculated according to previously mentioned return formulas (equations 2 and 3) and Bloomberg and Markit were the source for all indices' data.

As mentioned previously, microfinance investment funds in the studied sample are denoted in two different currencies, Euro and the U.S. dollar. We therefore distinguish two microfinance portfolios for which we will carry out the analysis separately. In order to reach consistent results with respect to risk-free rate adjusted monthly returns of given investment options we use two different risk-free rates - one denominated in EUR and second in USD. We define the risk-free interest rate as a rate of return on an asset with zero default risk and low liquidity risk. Therefore, risk-free returns are most commonly proxied by yields on government securities of the currency in question. We use yields on 10Y German government bonds and 10Y U.S. government bonds for the EUR and the USD microfinance funds portfolios respectively. Data for risk-free rates were obtained from Bloomberg.

\section{Results}

\section{Descriptive Evidence on the Performance of Microfinance Funds}

Before presenting the descriptive analysis of fund's financial performance with respect to chosen benchmarks and before reporting the regression results, we first provide a brief profile of microfinance investment funds as used in our study. Table 1 provides an overview of MIV and of the credit risk of microfinance institutions.

- insert Table 2 here -

Table 2 then lists all microfinance investment funds that are in our sample. 
It provides an overview of fund's inception date, its currency and legal status, share of diverse instruments in fund's portfolio, total assets under management as well as total volume of fund's assets allocated solely to microfinance. The legal structures of MIVs in the sample studied include the open-end collective investment scheme SICAV - part II (West European parallel to open-end mutual funds common mainly in the U.S.) and Fonds Commun de Placement (FCP - part II). ${ }^{18}$ Both forms are investment funds that offer redemption rights at any time during the course of investment. These forms of collective investment funds are common especially in European countries as France, Belgium, Luxembourg, Lichtenstein and Switzerland (Svárovská, 2009).

- insert Table 2 here -

The descriptive part of our analysis is based on key performance statistics of selected microfinance funds from January 2006 to September 2010 and includes volatility (standard deviation) of monthly returns, minimum and maximum $\mathrm{m} / \mathrm{m}$ returns, the percentage of months with negative returns and total per annum returns (Table 3 and Table 4). Panels A and B report returns of EUR and USD funds respectively, panel C shows return statistics for relevant benchmark portfolios. Indicated variables are then averaged across all observations within a subgroup of funds (arithmetic average can be skewed by one or a few outliers, therefore median is presented in addition to mean figures).

An overview of mean/median monthly yields of microfinance investment suggests comparable returns to those of the risk-free asset around $0.3 \%$ p.m. (although Euro funds were in average performing slightly worse than USD microfinance funds). Figures of mean/median monthly returns are, however, highly dependent on the chosen time span (this is well visible from Table 4 depicting highly varying p.a. returns). The volatility of monthly returns measured by standard deviations of returns is more important. Low standard deviations of MIVs compared to the benchmark indices stand out. The reason might be that the covered period of time was very volatile in terms of stock market returns and interest yields on fixed income instruments. Another aspect that may play a role is the monthly recalculation of funds' net asset values (which may absorb some of sudden major changes in values) in contrast to more vivid trading of stocks and bonds and daily changes in indices' values.

Most microfinance funds in Euro currency were launched within the study period and might have encountered negative returns during the initial months. This might stand behind the higher percentage of months with negative returns of funds in the Euro

\footnotetext{
${ }^{18}$ SICAV (Société d'Investissement à Capital Variable) is an open-end investment vehicle with a variable capital equal to the net asset value of the fund. Fonds Commun de Placement (FCP) is an unincorporated co-ownership of assets managed by a management company. The offered products are of the same nature as those of SICAVs even though FCPs may have access to more specialized and thinner markets and manage some marginal types of assets.
} 
portfolio (compared to the USD portfolio of funds). In spite of that, the percentage of negative monthly returns $(10-20 \%)$ is much lower for microfinance investments than for stock markets (47\% and $40 \%$ for world and emerging stocks respectively) and bond investments $(38 \%$ and $26 \%$ for European corporate bonds and emerging bonds respectively).

- insert Table 3 here -

When examining the total per annum returns (Table 4), we may detect the delayed effect of the financial crisis on the performance of microfinance funds. For all benchmark indices the year 2008 was crucial and all ended in red numbers (fixed income indices lost up to $10 \%$ in value, while stock indices (MSCI World and MSCI EM) dropped by $42 \%$ and 54\% respectively). In 2009, on the other hand, all benchmark markets experienced a significant correction (the emerging markets stock index grew by $74 \%$ ). In the case of microfinance investment funds, we observe a growing tendency in year-on-year returns until the end of 2008, with a subsequent slowdown in yearly yields in 2009 and part of 2010. For Euro denominated MIVs 2008 was on average the strongest year within our study period. Although it was less good for dollar funds (compared to previous year), both EUR and USD funds earned in average around 4-5\% p.a. A significant decline in p.a. returns followed only in 2009.

- insert Table 4 here -

Figure 2 reveals the evolution of the funds' net asset values and of index levels of all four benchmarks. All data are rebased to 100 on the graph start date. For reasons of clarity, only the evolution of the equally-weighted portfolio of microfinance funds is shown. Nevertheless a graphical analysis of separate funds would underline the main message of this figure which is that microfinance investment funds have offered modest but over time stable returns compared to given benchmarks.

- insert Figure 2 here -

Table 5 displays the correlation matrix of historical excess returns of equally-weighted Euro (in panel A) and U.S. dollar (in panel B) microfinance portfolios and excess returns of four selected market portfolios. Both microfinance portfolios have been negatively correlated with both stock and bond indices over the study period. An interesting point is that while USD portfolio's returns reported only slight negative correlation with MSCI stock indices (correlation coefficient of -0.14 and -0.17 with MSCI World and MSCI EM respectively), returns on microfinance portfolio denominated 
in Euro showed much stronger negative interdependence with a correlation coefficient reaching around -0.5 . The lower correlation with respect to fixed income indices than with respect to stock markets (for Euro funds) is justified by the fact that MIVs invest to a greater extent in interest-bearing securities than in equity. Negative correlations to market benchmarks suggest an opportunity to balance investor's risk profile if microfinance assets are added in a portfolio.

- insert Table 5 here -

\section{Regression Results}

In order to assess microfinance funds' performance and their market correlation, we estimate a CAPM-like model (equation 1) using risk-free rate adjusted monthly return data (natural $\log$ returns as specified in equation 3) of microfinance funds and market benchmarks. We analyze a given sample of 21 funds both at the individual fund level (using the cross-sectional approach) and at the aggregate level, using equally-weighted portfolio approach. In both cases funds denominated in Euro and the U.S. dollar are analyzed separately.

In order to estimate equation 1 we first run a cross-sectional regression of excess MIVs' returns against adjusted returns of particular market proxies using Stata. ${ }^{19}$ Table 6 displays p-values of the Breusch and Pagan Lagrange multiplier (LM) test for random effects and of the F-test for testing fixed group effects used to identify the best estimation method. ${ }^{20}$ Resulting p-values are for both Euro and U.S. dollar microfinance funds and with respect to all given indices very high. We may therefore accept the null hypotheses that the pooled regression model is the adequate one (against the fixed and random effects models).

- insert Table 6 here -

We run pooled OLS regression and perform tests for heteroskedasticity and autocorrelation (Table 7). Both the Breusch-Pagan/Cook-Weisberg test and the White's test suggest homoskedastic errors for all regression models of Euro denominated MIVs and the case when U.S. dollar MIVs are regressed against J.P. Morgan Emerging Bond Index. The most likely deviation from homoskedastic errors in the context of panel data is likely to be error variances specific to the cross-sectional unit (Stata Resources and Support: http://www.stata.com). The Modified Wald Test for groupwise

\footnotetext{
${ }^{19}$ Stata estimation algorithms take care of the unbalanced nature of the dataset.

${ }^{20}$ To test whether fixed effects model, random effects model or pooled model are adequate we interpret F-test statistic after Stata command "xtreg dependent_variable independent_variables, fe" and the Breusch and Pagan LM test using Stata command "xttest0" after "xtreg dependent_variable independent_variables, re."
} 
heteroskedasticity confirms this suggestion in our case. The Wooldridge test for first-order autocorrelation of residuals in Panel D in Table 7 suggests autocorrelation for regressions of MIVs in U.S. dollar. ${ }^{21}$ Due to given results, we estimate the pooled model using "panel-corrected standard errors" (PCSEs) estimates for linear cross-sectional time-series models where the parameters are estimated by Prais-Winsten regression. ${ }^{22}$ Beck and Katz (1995) showed that the "feasible generalized least squares" (FGLS) procedure, which is also commonly used in such cases, "has extremely poor statistical properties unless the length of series is significantly higher than the number of cross-sections, which is rare, and the method is seldom used any more." Beck (2008) supports the choice of PCSEs in place of the OLS standard errors when a correction of standard errors is necessary due to contemporaneously correlated and panel heteroskedastic errors.

- insert Table 7 here -

\section{Systematic Risk Measured by Beta}

Regression estimates of beta and related R-squared measures are presented in Table 8 (panels $\mathrm{A}$ and $\mathrm{B}$ refer to cross-sectional and equally-weighted portfolio approaches $^{23}$ respectively). Beta estimates are for all regressions negative, ranging from -0.07 to figures close to zero. For the case of panel data analysis all results, except for the relationship between USD denominated funds and world's markets stocks (MSCI World), are statistically significant (on at least $10 \%$ significance level). ${ }^{24}$ When equally-weighted portfolio approach is used, estimates are statistically significant for all regressions of EUR microfinance portfolio and for the relationship between USD

21 We use Stata commands "hettest, fstat" and "whitetst" after "regress dependent_variable independent_variables" for the Breusch-Pagan/Cook-Weisberg test and the White's test respectively. For the modified Wald Test for groupwise heteroskedasticity we use "xttest3" after "xtgls dependent_variable independent_variables." Wooldridge test for first-order autocorrelation of residuals is carried out using "xtserial dependent_variable independent_variables" command.

${ }^{22}$ OLS regression might lead to statistically inefficient results as well as to wrong standard errors. When computing the standard errors and the variance-covariance estimates, PCSE in Stata assumes that the disturbances are heteroskedastic and contemporaneously correlated across panels. We assume first-order autocorrelation within panels and that the coefficient of the AR (1) process is specific to each panel. Chosen "pairwise" option specifies how missing observations in unbalanced panels should be treated when estimating the interpanel covariance matrix of the disturbances, i.e. "pairwise" specifies that for each element in the covariance matrix, all available observations (periods) that are common to the two panels contributing to the covariance are used to compute the covariance. (Stata Resources and Support: http://www.stata.com). We use a Stata command: "xtpcse dependent_variable independent_variables, correlation(psar1) pairwise."

${ }^{23}$ In the case of equally-weighted microfinance portfolio approach, we run OLS time series regression with heteroskedasticity and autocorrelation consistent (HAC) standard errors taking into account heteroskedasticity and autocorrelation of residuals for regression against certain indices.

${ }^{24}$ Hereinafter and if not specified otherwise, the term "statistically significant" refers to significant on at least a $10 \%$ significance level. 
portfolio and the emerging markets bond index (J.P. Morgan EMBI+). Beta measures the sensitivity of an asset's return to moves in returns of benchmark indices. Close-to-zero estimates of beta suggest that returns of microfinance funds in the sample do not move in the same direction as returns on investment in both world and emerging markets' stocks, and fixed income instruments.

While the beta estimates measure the direction of correlation (which is slightly negative in our case), the model's R-squared measures the tightness of the correlation in the sense of how much of MIV's moves in returns could be explained by moves in returns of benchmark indices. The explanatory power of the panel data models (measured by R-squared) is low, reaching less than $5 \%$. The remaining share of variance in funds' returns is due to other aspects than the trading sentiment on stock or bond markets. Higher R-squared for models of Euro denominated funds using the weighted portfolio approach reaching up to $26 \%$ might be due to differences in two chosen calculation approaches. This, however, does not matter for drawn conclusion based significantly on the zero returns' sensitivity to benchmarks shown by beta. This translates into zero systematic (non-diversifiable) risk of microfinance funds. Therefore an addition of microfinance assets to already well-diversified portfolio (against the unsystematic risk) could reduce the systematic risk of the whole portfolio. The specific risk is perceived to be high as microfinance is not yet defined as a specific asset class. That is why there is a need for a portfolio that is already well diversified against the specific risk, to which we would add microfinance assets to lower the market exposure of the overall portfolio.

- insert Table 8 here -

\section{Performance Measured by Alpha}

The regression estimates for the Jensen's alpha measure are shown in Table 9. The only statistically significant estimates were those using the cross-sectional approach (except for regression of Euro microfinance portfolio on MSCI World Index). Significant estimates reveal that over the given time span microfinance funds outperformed benchmark indices by between 22 to 31 basis points (in terms of monthly returns). There is virtually no difference across models taking into account different benchmarks, on the other hand, U.S. dollar MIVs seems to be more efficient in terms of alpha, i.e. added return over the theoretical expected return compensating an investor for the 
systematic risk. ${ }^{25}$ The difference between Euro and U.S. dollar denominated funds' performance shown by different alpha estimates is in line with pure statistical evidence of mean monthly returns over the studied time span of the two currency groups of funds discussed in section 5 and shown Table 3.

- insert Table 9 here -

\section{Test of Stability of Alpha and Beta Estimates}

Taking into account the fact that the study period covers the so called bull and bear stock markets, and based on graphical evidence from Figure 2, we examine whether estimated coefficients were stable in time and therefore whether we could rely on estimates from pooled observations. As breaking points we take October 2007 and February 2009, when both stock indices reached their maximum and minimum levels respectively within the study period (see Figure 2). Those dates, however, do not represent any significant breaking points for the fixed income indices nor can any other significant breaking points worth of separate structural stability analysis be identified. Although a comparable analysis with respect to fixed income indices would be desirable due to the similar nature of underlying investment instruments, the lack of a distinct breaking point would not allow us to draw any meaningful conclusions from found estimates. For this reason we may focus only on the relationship of microfinance assets to equity investment and we consider the beta and alpha estimates with respect to fixed income indices presented above as stable.

We split the sample into three subperiods: January 2006 - October 2007, November 2007 - February 2009 and March 2009 - September 2010 with 22, 16 and 19 time observations respectively. A commonly used measure to test the structural stability of regression parameters is the Chow test. ${ }^{26}$

We test the null hypothesis given in equation 4 :

\footnotetext{
${ }^{25}$ Hereinafter and if not specified otherwise, the term "added return" (measured by the Jensen's alpha) refers to added return over the theoretical expected return implied by the CAPM that compensate an investor for the systematic risk measured by beta. The economic meaning of this term is different from above defined "excess returns" or "adjusted returns", which relate to monthly returns of microfinance investment funds or benchmark indices adjusted for the respective risk-free rate.

${ }^{26}$ For example Frost et al. (2008) perform the same test in examining the structural stability of estimates of CAMP-like model for socially responsible investment funds in Australia.
} 


$$
\begin{aligned}
& H_{0}:\left(r_{i t}-r_{f t}\right)^{(1)}=\alpha_{i}+\beta_{i}\left(r_{M t}-r_{f t}\right)^{(1)}+\varepsilon_{t}^{(1)} \\
& \left(r_{i t}-r_{f t}\right)^{(2)}=\alpha_{i}+\beta_{i}\left(r_{M t}-r_{f t}\right)^{(2)}+\varepsilon_{t}^{(2)} \\
& \left(r_{i t}-r_{f t}\right)^{(3)}=\alpha_{i}+\beta_{i}\left(r_{M t}-r_{f t}\right)^{(3)}+\varepsilon_{t}^{(3)} \\
& \text { against the alternative } H_{A}:\left(r_{i t}-r_{f t}\right)^{(1)}=\alpha_{i}^{(1)}+\beta_{i}^{(1)} \cdot\left(r_{M t}-r_{f t}\right)^{(1)}+\varepsilon_{t}^{(1)} \\
& \left(r_{i t}-r_{f t}\right)^{(2)}=\alpha_{i}^{(2)}+\beta_{i}^{(2)} \cdot\left(r_{M t}-r_{f t}\right)^{(2)}+\varepsilon_{t}^{(2)} \\
& \left(r_{i t}-r_{f t}\right)^{(3)}=\alpha_{i}^{(3)}+\beta_{i}^{(3)} \cdot\left(r_{M t}-r_{f t}\right)^{(3)}+\varepsilon_{t}^{(3)}
\end{aligned}
$$

where $r_{i t}$ and $r_{M t}$ are returns of an microfinance fund or portfolio $i$ and of a market portfolio $M$ respectively, $r_{f t}$ is yield on a risk-free asset in time $t$ and $\varepsilon_{t}$ is the error term for time t. $\alpha_{i}$ and $\beta_{i}$ are Jensen's alpha measure and portfolio beta respectively. Numbers in upper index in parentheses reflect chosen subperiods - (1): January $2006-$ October 2007; (2): November 2007 - February 2009 and (3): March 2009 - September 2010.

On a chosen 5 percent significance level we reject the null hypothesis of stability of regression parameters within the whole study period for both Euro and U.S. dollar microfinance funds using both the cross-sectional approach and the weighted portfolio approach (see Table 10 for the p-values of the Chow test). The Chow test suggests that either alpha or beta (or both) had changed from one period to another.

- insert Table 10 here -

Table 11 displays estimates of Jensen's alpha and regression betas individually for the three subperiods with respect to both MSCI indices. Results of the market risk measure beta for EUR funds were significant and negative for the first period (when cross-sectional approach was used) as well as for the interim period when stock indices were falling (using both approaches). The analysis of the USD denominated funds was less successful in terms of beta significance and does not allow us to draw any conclusions specific to the U.S. dollar investment. There are only marginal differences in significant beta estimates across all three periods and globally all betas are close to zero, resulting in the same suggestion as it was put forward in the overall analysis concerning low levels of systematic risk of microfinance assets.

Given that there are no particularly important differences in betas for the three subperiods, the structural break in regression coefficients confirmed by the Chow test is likely to be due to changes in Jensen's alphas. In the interpretation of results for alpha estimates we focus on the panel data analysis approach, which results in more statistically significant estimates. It seems that the first and the second period, although they 
were different in terms of stock market sentiment, were successful for microfinance funds. Estimated levels of alpha coefficients of Euro denominated funds are similar for both periods and for both indices (reaching around $0.3-0.4 \%$ of added $\mathrm{m} / \mathrm{m}$ returns), and they contributed to an increase of pooled estimates of Jensen's alpha in Table 9. A slight decrease in added returns after October 2007 (end of the first period) is visible for USD funds against both indices. This suggests that U.S. dollar denominated funds were, in terms of returns, more affected by the performance of benchmark markets (that were between November 2007 and February 2009 falling down) than the Euro microfinance funds. From the end of February 2009 (the second breaking point), we observe a clear trend of decline in added returns of microfinance funds of both currencies.

Jensen's alpha measures added returns relative to returns of benchmark indices. Therefore, the decline in third period alpha estimates may be due to both the actual decline in MIVs returns and/or the rebound of benchmark markets. There is no doubt that since March 2009 both MSCI indices started to grow in levels again and microfinance funds, therefore, became relatively less profitable. On the other hand, as shown in the statistics of total year-on-year returns in Table 4, we may observe an actual decline in average total returns for the year of 2009. Therefore, as was already discussed in section 4, the impact of the financial crisis (mostly in the second period) might have had only a delayed effect on developing countries and therefore also on the profitability of microcredits. This could be connected to a possibly higher share of written-off loans, or less favorable refinancing conditions of microfinance institutions that both translate into lower profits (i.e. lower value of equity shares in MFIs held by investment funds). Lower profits could have equally stopped or decelerate the pace of MFIs' expansion for which new loans (provided by investment funds) are needed.

The second theory that would underline a significantly lower alpha estimate for the period from March 2009 until September 2010, and which is pertinent only for the Euro denominated funds, might be related to the composition of funds' sample. Although estimates from the last period cover more funds and should therefore be more realistic, they could be prone to inefficiencies in terms of outlier monthly returns. This is due to the fact that about half of the funds included were launched during this period (or a short time before) and negative month-on-month returns may have been connected to start-up phase difficulties.

- insert Table 11 here -

\section{Conclusions and Limitations}

The aim of this study was to confirm or reject two hypotheses related to the risk profile and return qualities of specialized investment funds that invest in debt instruments and equity of microfinance institutions.

With regard to the dependence of microfinance funds' returns on the performance 
of stock and fixed income markets in developed and emerging economies, we found a slightly negative correlation when measured by both the correlation coefficient as well as by the portfolio beta measure. Significant beta estimates are slightly negative for regressions against all indices but close to zero when both approaches - the cross-sectional regression as well as the equally-weighted portfolio of microfinance funds - are used. We may therefore accept the first hypothesis that "returns on investment in microfinance investment funds are not positively correlated with returns on the market portfolio" (proxied by four chosen indices). However, the analysis of microfinance funds denominated in the U.S. dollar did not yield very significant beta estimates. Therefore, conclusions drawn from the analysis of systematic risk are specific only to Euro denominated funds. Close-to-zero betas were also confirmed by a separate analysis of three subperiods (chosen according to the stock indices' development) with respect to equity indices. Such results suggest an independence (or slightly negative dependence) of microfinance funds' returns on the performance of global and emerging stock and bond markets. Zero systematic risk of microfinance assets could therefore positively contribute to a better diversification of broader portfolios against the impact of the investment sentiment on global markets.

Although an indirect investment in microfinance through structured investment vehicles is surely less risky than exposure to one or few MFIs (due to diversification of funds' manager, indirect exposure to foreign exchange rate risk as well as higher liquidity of investment assured by redemption rights), such investment still brings along specific risk connected to funds' underlying assets, which may imperil MFIs' ability to generate profit or to respond to their obligations on loans repayment. The liquidity issue remains important because of a given time notice that needs to be respected when redemption rights are exercised. Some funds, therefore, suggest that the investment in funds' shares should be viewed as a medium to long-term investment. Bearing in mind the still rather high specific risk of microfinance investment, an inclusion of microfinance assets intended to lower portfolio's overall market exposure is desirable when the current portfolio is already well diversified against the unsystematic risk.

Return qualities of microfinance funds were proxied by the Jensen's alpha, which measures the added returns on an asset (i.e. microfinance funds) over returns that an investor would deserve to compensate him for the systematic risk of holding such asset (the systematic risk is measured by beta). Estimates were on average significant for both Euro and the U.S. dollar denominated funds, with USD funds that reached on average higher added returns in terms of alpha compared to their currency concurrent. A separate analysis of added returns of MIVs with regard to stock investment over three subperiods has shown that during the last period (from March 2009 until September this year) microfinance funds could only to a lesser extent compete for investors' interest in terms of expected added returns. Overall, nevertheless, added returns of microfinance investment funds against all indices proved to be positive during the course of the study. This suggests that an investor that includes shares of microfinance investment funds in his portfolio does not pay (in terms of opportunity costs) for his decision to invest in socially responsible assets. As a consequence, we may confirm our second hypothesis that "returns on investment in microfinance investment funds exceed the returns 
on the market portfolio." The latter together with reported near-to-zero beta estimates as a proxy for the systematic risk are perceived to be the main advantages of the inclusion of microfinance assets in a portfolio compared to pure stock or bond portfolios.

Previous research on the performance of microfinance has examined the profitability of microfinance institutions and its dependence on the performance of global financial markets or national economies. All previous studies treated the microfinance institutions directly and revealed that on average the profitability of MFIs is not correlated with the performance of global financial markets (Kraus and Walter, 2009 and Galema et al., 2011) but may be susceptible to the growth of domestic economies (Ahlin et al., 2011 and Kraus and Walter, 2009). The objective of our study was to examine the risk-return profile of specialized microfinance investment funds investing in debt or equity of microfinance institutions and acting as financial intermediaries between the final investor and MFIs. There are two advantages connected to the approach of evaluation of investment funds rather than MFIs. The first is the availability of monthly data, and the second is the focus on the actual investors' returns (in terms of the change in net asset values per share). On the other hand, we identify several limitations in our results. Microfinance funds are rather a recent phenomenon and before 2006 (i.e. the start of our examination period) there were only a few active commercial funds. For this reason we may not examine a longer time series to be able to capture the effect of the business cycle development.

Likewise, the chosen approach focuses on quite a different group of MFIs. While previous studies took into account financial indicators available for as many MFIs as possible from all over the world (MFIs reporting to MIX Market database), our analysis may have targeted at the end only the most successful and commercially viable MFIs. The reason behind this is the selection process of funds' asset managers who seek to invest in suitable (i.e. successful and sustainable) MFIs, which might be concentrated only in certain world regions. Koivulehto (2007) and Galema et al. (2011) examine MFIs' profitability from a regional point of view and find out that microfinance institution in Latin America and Eastern Europe and Central Asia are the most profitable (within their samples). Table 2 illustrates the regional breakdown of the investment of studied funds that effectively concentrate most on the two previously mentioned world regions. As a consequence, we may conclude that our results would not reflect the entire microfinance sector, but may be biased with respect to the group of most effective MFIs. On the other hand, this is not a limitation for the purpose of this study, which is to introduce microfinance investment funds as an investment alternative against pure stock and bond portfolio.

We may conclude that given the supply-demand gap in the sector of small business loans in developing and transition economies, the prospective of future growth in the sector is realistic if necessary funding is available for expanding microfinance institutions. Our study showed that microfinance assets may be perceived as a good systematic risk diversification tool, which generates adequate risk-adjusted returns and may therefore be attractive to investors from developed markets. Furthermore, a greater emphasis of socially responsible investment is becoming more important and 
microfinance as part of the socially responsible type of investment may be able to profit from this growing tendency. As a consequence, we may hope for further expansion of MFIs' activities and better development of the regions in which they act. 


\section{References}

Ahlin, C., Lin, J. \& Maio, M. (2011). Where does microfinance flourish? Microfinance institution performance in macroeconomic context. Journal of Development Economics, 95 (2): 105-120.

Armendáriz de Aghion, B. \& Morduch, J. (2005). The Economics of Microfinance. MIT Press, Cambridge, MA.

Association of the Luxembourg Fund Industry. (2010). Luxembourg Regulated Investment Vehicles: An overview of the regulatory requirements. Available at: http://www.alfi.lu/sites/alfi.lu/files/WEB_Investment_Vehicles_2010.pdf （accessed October 15, 2010).

Bauer, M., Chytilova, J. \& Morduch J. (2008). Behavioral Foundations of Microcredit: Experimental and Survey, Evidence From Rural India. IES Working Paper No. 28, Institute of Economic Studies, Charles University, Prague.

Beck, N. (2008). Time-series cross-section methods. In Box-Steffensmeier, J.M., Brady, H.E. \& Collier, D. (editors) The Oxford Handbook of Political Methodology. Oxford University Press, Oxford.

Beck, N. \& Katz, J.N. (1995). What To Do (and Not To Do) with Time-Series CrossSection Data. American Political Science Review, 89: 634-47.

Brown, S.J., Goetzmann, W., Ibbotson, R.G. \& Ross, S.A. (1992). Survivorship Bias in Performance Studies. The Review of Financial Studies, 5 (4): 553-580.

Byström, H.N. (2008). The Microfinance Collateralized Debt Obligation: A Modern Robin Hood? World Development, 36 (11): 2109-2126.

Cassar, A. \& Wydick, B. (2010). Does Social Capital Matter? Evidence from a FiveCountry Group Lending Experiment. Oxford Economic Papers, 62 (4): 715-739.

Christen, R.P. \& Drake, D. (2002). Commercialization: the new reality of microfinance? In Drake, D. \& Rhyne, E. (editors), The Commercialization of Microfinance: Balancing Business and Development, Kumarian Press, Bloomfield, CT. 
Christen, R.P., Jayadeva, V. \& Rosenberg, R. (2004). Financial Institutions with a "Double Bottom Line": Implications for the Future of Microfinance, Occasional Paper No. 8, July 2004, CGAP, Washington. Available at: http://www.microfinancegateway.org/p/site/m/template.rc/1.9.26340 (accessed October $15,2010)$.

Cull, R., Demirguc-Kunt, A. \& Morduch, J. (2009). Microfinance meets the market. Journal of Economic Perspectives, 23 (1): 167-92.

de Sousa-Shields, M. \& Frankiewicz, C. (2004). Financing Microfinance Institutions: The Context for Transitions to Private Capital. USAID Micro Report No. 8. Available at: http://www.esglobal.com/pdf/Financing\%20Microfinance\%20 Institutions.pdf (accessed October 15, 2010).

Deutsche Bank Research. (2007). Microfinance: An emerging investment opportunity. Deutsche Bank Research, Frankfurt am Main.

Ferson, W.E. \& Schadt R.W. (1996). Measuring Fund Strategy and Performance in Changing Economic Conditions. The Journal of Finance, 51 (2): 425-461.

Forster, S. \& Reille, X. (2008). Foreign Capital Investment in Microfinance: Balancing Social and Financial Returns. Focus Note No. 44, February 2008, CGAP, Washington. Available at: http://www.microfinancegateway.org/p/site/m/template.rc /1.9.29212 (accessed October 15, 2010).

Frost, G., Jones, S., Loftus, J. \& van der Laan, S. (2008). The Investment Performance of Socially Responsible Investment Funds in Australia. Journal of Business Ethics, 80 (2): 181-203.

Galema, R., Lensink, R. \& Spierdijk, L. (2011). International Diversification and Microfinance. Journal of International Money and Finance, 30 (3): 507-515.

Giné, X., Jakiela, P., Karlan, D. \& Morduch, J. (2010). Microfinance Games. American Economic Journal: Applied Economics, 2 (3): 60-95.

Giné, X. \& Karlan, D. (2009). Group versus Individual Liability: Long Term Evidence from Philippine Microcredit Lending Groups. Economics Department Working Paper No. 61, Yale University, New Haven, CT. Available at: 
http://www.econ.yale.edu/ddp/ddp50/ddp0061.pdf (accessed October 15, 2010).

Goodman, P. (2007). Microfinance Investment Funds : Objectives, Players, Potential. In Matthäus-Maier, I. \& von Pischke, J. D. (editors). Microfinance Investment Funds: Leveraging Private Capital for Economic Growth and Poverty Reduction. Springer, Berlin/Heidelberg/New York.

Gonzalez, A. (2007). Resilience of Microfinance Institutions to National Macroeconomic Events: An Econometric Analysis of MFI Asset Quality. MIX Discussion Paper No. 1, Microfinance Information Exchange, Inc., Washington. Available at: http://mpra.ub.uni-muenchen.de/4317 (accessed October 15, 2010).

Gonzalez, A., Narain, S. \& Rosenberg, R. (2009). The New Moneylenders: Are the Poor Being Exploited by High Microcredit Interest rates? Occasional Paper No. 15, February 2009, CGAP, Washington. Available at http://www.cgap.org/p/site/c/template.rc/1.9.9534 (accessed October 15, 2010).

Janda, K. \& Svárovská, B. (2009a). Investing into Microfinance Investment Funds. IES Working Paper No. 32, Institute of Economic Studies, Charles University, Prague.

Janda, K. \& Svárovská, B. (2009b). The Problems of Correlation in the Financial Risk Management - the Contribution of Microfinance. In: Málek, J. (editor). Risk Management 2009. Oeconomica, Prague.

Janda, K. \& Svárovská, B. (2010). Investing into Microfinance. Journal of Business Economics and Management, 11 (3): 483-510.

Kneiding, C., Reille, X., Rozas D., Rozeira de Mariz, F. \& O’Donohoe, N. (2010). All Eyes on Microfinance Asset Quality: Microfinance Global Valuation Survey 2010. CGAP and J.P. Morgan. Available at: http://www.jpmorgan.com/pages /jpmorgan/investbk/research/mfi (accessed October 15, 2010).

Koivulehto, H. K. (2007). Should We Invest in Microcredit? A Financial Analysis of Microcredit from a USD-Investor's Perspective. Paris December 2007 Finance International Meeting AFFI-EUROFIDAI Paper. Available at: http://ssrn.com/abstract=1071668 (accessed October 15, 2010).

Krauss, N. A. \& Walter, I. (2009). Can Microfinance Reduce Portfolio Volatility? 
Economic Development and Cultural Change, 58 (1): 85-110.

Lauer, K. (2008). Transforming NGO MFIs: Critical Ownership Issues to Consider. Occasional Paper No. 13, June 2008, CGAP, Washington. Available at: http://www.microfinancegateway.org/p/site/m/template.rc/1.9.31160/ (accessed October $15,2010)$.

Ledgerwood, J. \& White, V. (2006). Transforming Microfinance Institutions: Providing Full Financial Services to the Poor. The World Bank and The MicroFinance Network, Washington.

Lintner, J. (1965). The Valuation of Risk Assets and the Selection of Risky Investments in Stock Portfolios and Capital Budgets. The Review of Economics and Statistics, 47 (1): 13-37.

Microfinance Information Exchange, Inc. (2004, 2005, 2006, 2007, 2008) Annual MFI Benchmarks for years from 2005 to 2008. Available at: http://www.themix.org/publications (accessed July 15, 2010).

MicroRate. (2010). State of Microfinance Investment: The MicroRate 2010 MIV Survey. MicroRate, Inc., Virginia. Available at: http://www.microrate.com/state-ofmicrofinance-investment-2010-microrate-miv-survey (accessed October 15, 2010).

Sharpe, W.F. (1964). Capital Asset Prices: A Theory of Market Equilibrium under Conditions of Risk. Journal of Finance, 19 (3): 425-442.

Svárovská, B. (2009). Investment Opportunities in Microfinance and their Attractiveness for Global Market Players. Thesis with distinction from the Dean of the Faculty of Social Sciences, Charles University, Prague. 


\section{Figures and Tables}

\section{Figure 1 - Microfinance Investment Vehicles}

MIV microfinance assets $\square$ Total MVI portfolio assets - Number of MIV participants

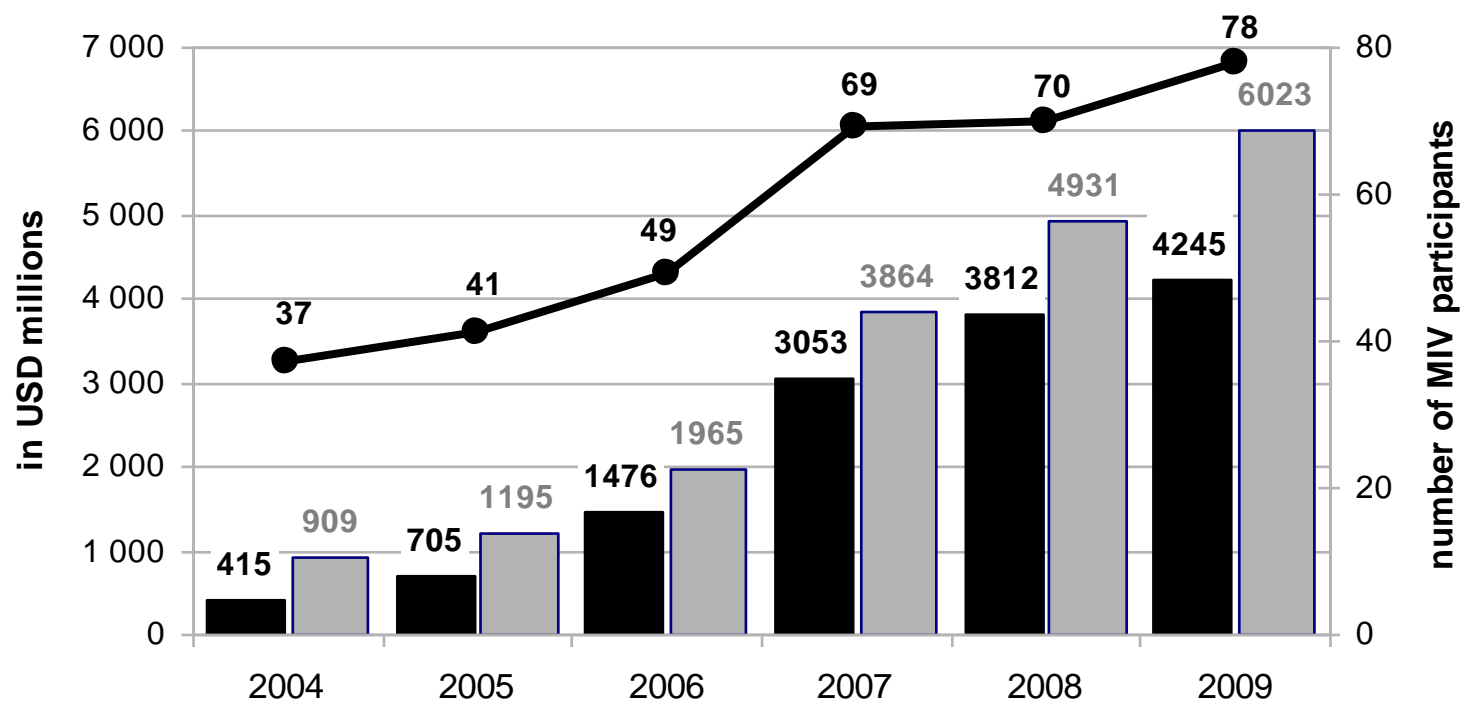

Notes: Figures are based on annual survey carried out by MicroRate, a rating agency dedicated to the evaluation of microfinance institutions and microfinance investment vehicles. They do not represent figures for all existing MIVs and only those who contribute to the annual survey and may, therefore, be slightly underestimated.

Source: MicroRate (2010) 
Figure 2 - Historical Performance of Microfinance Portfolio against Benchmark Indices

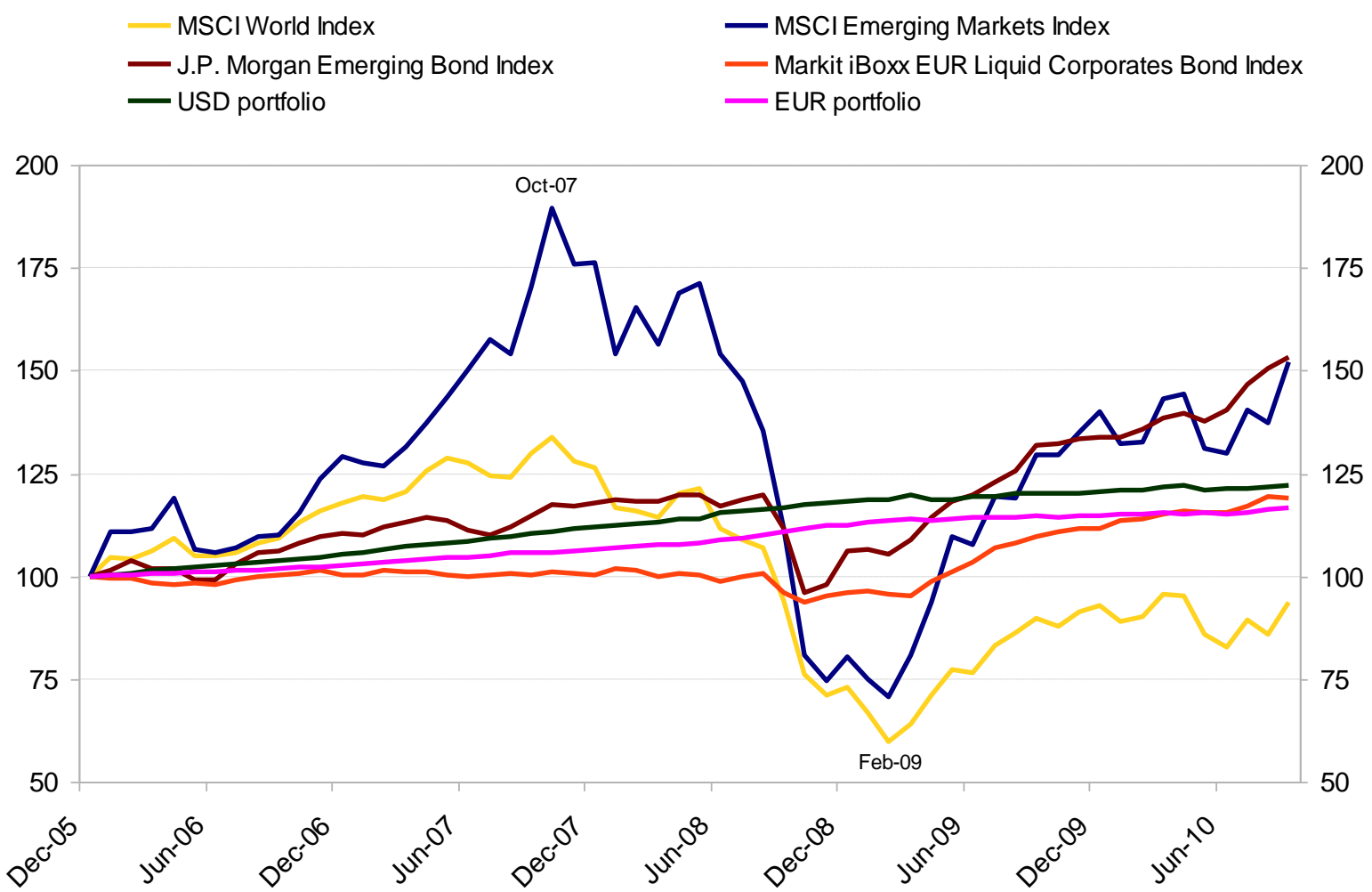

Source: own calculations based on data from Bloomberg and Markit

Table 1 - Median Credit Risk of Microfinance Institutions

\begin{tabular}{lcccccc}
\hline \hline & & 2004 & 2005 & 2006 & 2007 & 2008 \\
\hline Portfolio at Risk > 30 Days & $\%$ & 2.1 & 2.2 & 2.8 & 2.7 & 3.1 \\
Portfolio at Risk > 90 Days & $\%$ & 0.9 & 1.0 & 1.4 & 1.4 & 1.6 \\
Write-off Ratio & $\%$ & 1.3 & 1.3 & 1.1 & 1.1 & 1.0 \\
Loan Loss Rate & $\%$ & 1.0 & 1.0 & 0.9 & 1.0 & 0.8 \\
Number of MFls included in the sample & & 302 & 446 & 704 & 890 & 1084 \\
\hline
\end{tabular}

Notes: Portfolio at Risk > 30 (90) Days = (portfolio overdue more than 30 (90) days + renegotiated portfolio) / adjusted gross loan portfolio; Write-off Ratio = value of loans written off $/$ average gross loan portfolio; Loan Loss Rate $=$ (value of loans written off - loans recovered) / average gross loan portfolio.

While the total number of existing MFIs was calculated on 2420 institutions as of December 2008, figures in the table are based on data of those MFIs that voluntarily report to the MIX Market database. Such bias does not matter to our issue as these MFIs are also likely to attract foreign capital and are therefore of our interest.

Source: Microfinance Information Exchange, Inc. (2004, 2005, 2006, 2007, 2008) 
Table 2 - Overview of Studied Microfinance Investment Funds

\begin{tabular}{|c|c|c|c|c|c|c|c|c|c|}
\hline \multirow[b]{2}{*}{ MIV } & \multirow[b]{2}{*}{ Currency / Class } & \multirow[b]{2}{*}{ Legal Status } & \multirow[b]{2}{*}{$\begin{array}{l}\text { Inception } \\
\text { date } \\
\text { (liquidation } \\
\text { date) }\end{array}$} & \multicolumn{3}{|c|}{ Assets } & \multirow[b]{2}{*}{ as of (date) } & \multirow[b]{2}{*}{$\begin{array}{l}\text { Minimum } \\
\text { investment }\end{array}$} & \multirow[b]{2}{*}{ NAV Calculation } \\
\hline & & & & $\begin{array}{l}\text { Fund Assets (Net } \\
\text { Asset Value) }\end{array}$ & $\begin{array}{l}\text { Fund Assets } \\
\text { Allocated to MF } \\
\text { Investments }\end{array}$ & $\begin{array}{l}\% \text { of Fund } \\
\text { Assets } \\
\text { Allocated to MF } \\
\text { Investments }\end{array}$ & & & \\
\hline \multirow{2}{*}{$\begin{array}{l}\text { responsAbility Global } \\
\text { Microfinance Fund }\end{array}$} & EUR & \multirow{2}{*}{ FCP - Part II } & \multirow{2}{*}{ Nov-03 } & \multirow{2}{*}{502226258 USD } & \multirow{2}{*}{364681596 USD } & \multirow{2}{*}{$72.6 \%$} & \multirow{2}{*}{ 30-Sep-10 } & 1000 EUR & \multirow{4}{*}{$\begin{array}{l}\text { on the last } \\
\text { Luxembourg banking } \\
\text { day of the month }\end{array}$} \\
\hline & USD & & & & & & & 1000 USD & \\
\hline $\begin{array}{l}\text { respons Ability Mikrofinanz } \\
\text { Fund }\end{array}$ & EUR & SICAV - Part II & May-07 & 105932985 EUR & 85511426 EUR & $80.7 \%$ & 30-Sep-10 & 1000 EUR & \\
\hline $\begin{array}{l}\text { responsAbility Microfinance } \\
\text { Leaders Fund }\end{array}$ & USD & SICAV - Part II & Nov-06 & 145407702 USD & 111847320 USD & $76.9 \%$ & 30-Sep-10 & 1000000 USD & \\
\hline \multirow{3}{*}{$\begin{array}{l}\text { Dual Return - Vision } \\
\text { Microfinance Fund }\end{array}$} & USD / Class P & \multirow{3}{*}{ SICAV - Part II } & \multicolumn{2}{|l|}{ May-06 (Jul-09) } & \multirow{3}{*}{\multicolumn{2}{|c|}{$\begin{array}{l}\text { Based on fund's prospectus a } \\
\text { maximum of } 75 \% \text { of the fund's net } \\
\text { assets can be invested in } \\
\text { microfinance assets }\end{array}$}} & \multirow{3}{*}{ 27-Sep-10 } & $\mathrm{n} / \mathrm{a}$ & \multirow{3}{*}{$\begin{array}{l}\text { on } 10 \text { th } \& 25 \text { th of } \\
\text { each month }\end{array}$} \\
\hline & EUR / Class P & & Apr-06 & 91857031 EUR & & & & 1000 EUR & \\
\hline & EUR / Class I & & Sep-07 & & & & & 125000 EUR & \\
\hline \multirow{2}{*}{$\begin{array}{l}\text { Dexia Micro-Credit Fund - } \\
\text { BlueOrchard Debt Sub-Fund }\end{array}$} & EUR & \multirow{2}{*}{ SICAV - Part II } & Apr-03 & \multirow{2}{*}{515514918 USD } & \multirow{2}{*}{424943704 USD } & \multirow{2}{*}{$82.4 \%$} & \multirow{2}{*}{$6-$ Oct-10 } & 10000 EUR & \multirow{2}{*}{$\begin{array}{l}\text { on first Wednesday of } \\
\text { each month }\end{array}$} \\
\hline & USD & & Sep-98 & & & & & 10000 USD & \\
\hline $\begin{array}{l}\text { Edmond de Rothschild -Saint } \\
\text { - Honore Microfinance }\end{array}$ & EUR & SICAV - Part II & Nov-05 & 6490000 EUR & $\mathrm{n} / \mathrm{a}$ & $63.1 \%$ & 1-Apr-10 & $\mathrm{n} / \mathrm{a}$ & $\begin{array}{l}\text { on the first Thursday } \\
\text { of each month }\end{array}$ \\
\hline BBVA Codespa Microfinanzas & EUR & $\begin{array}{c}\text { Open-end } \\
\text { investment fund }\end{array}$ & Oct-06 & 28000000 EUR & 19700000 EUR & $70.4 \%$ & 1-Sep-10 & 50000 EUR & $\begin{array}{l}\text { on the first working } \\
\text { day each month }\end{array}$ \\
\hline $\begin{array}{l}\text { Wallberg Global Microfinance } \\
\text { Fund }\end{array}$ & $\begin{array}{l}\text { EUR / Class I } \\
\text { EUR / Class P }\end{array}$ & FCP - Part II & Oct-08 & 40400000 EUR & 32000000 EUR & $79.2 \%$ & 30-Sep-10 & 1000 EUR & monthly \\
\hline Dutch Microfund & EUR & $\begin{array}{c}\text { Open-end } \\
\text { investment fund }\end{array}$ & May-08 & $\mathrm{n} / \mathrm{a}$ & $\mathrm{n} / \mathrm{a}$ & $\mathrm{n} / \mathrm{a}$ & & 1000 EUR & $\begin{array}{l}\text { on the } 10 \text { th business } \\
\text { day each month }\end{array}$ \\
\hline $\begin{array}{l}\text { Erste-Sparinvest Espa Vinis } \\
\text { Microfinance }\end{array}$ & EUR & $\begin{array}{l}\text { Open-end } \\
\text { investment fund }\end{array}$ & Jan-10 & 24852097 EUR & $\mathrm{n} / \mathrm{a}$ & $\begin{array}{l}100 \% ; \text { based } \\
\text { on fund's } \\
\text { prospectus }\end{array}$ & 30-Sep-10 & $\mathrm{n} / \mathrm{a}$ & monthly \\
\hline & EUR / Class I-cap & & Apr-09 & & & & & 250000 EUR & \\
\hline & EUR / Class B-cap & & Jun-09 & & & & & $\mathrm{n} / \mathrm{a}$ & \\
\hline Triodos Microfinance Fund & EUR / Class B-dis & SICAV - Part II & Jun-09 & 52400000 EUR & 41300000 EUR & $78.8 \%$ & 30-Jun-10 & $\mathrm{n} / \mathrm{a}$ & $\begin{array}{l}\text { on last business day } \\
\text { of each month }\end{array}$ \\
\hline & EUR / Class I-dis & & Feb-09 & & & & & 250000 EUR & \\
\hline & EUR / Class R-cap & & Jul-09 & & & & & $\mathrm{n} / \mathrm{a}$ & \\
\hline $\begin{array}{l}\text { EMF Microfinance Fund } \\
\text { AGmvK }\end{array}$ & $\begin{array}{l}\text { USD / Class A } \\
\text { USD / Class T }\end{array}$ & $\begin{array}{l}\text { Open-end } \\
\text { investment fund }\end{array}$ & Nov-09 & $\mathrm{n} / \mathrm{a}$ & $\mathrm{n} / \mathrm{a}$ & $\mathrm{n} / \mathrm{a}$ & & $\begin{array}{r}\text { an equivalent of } \\
\text { CHF 250,000 in } \\
\text { USD }\end{array}$ & monthly \\
\hline
\end{tabular}


Table 3 (continued) - Overview of Studied Microfinance Investment Funds

\begin{tabular}{|c|c|c|c|c|c|c|c|c|c|c|c|c|c|}
\hline \multirow[b]{2}{*}{ MIV } & \multirow[b]{2}{*}{ Currency / Class } & \multicolumn{4}{|c|}{ Instruments } & \multicolumn{8}{|c|}{ Geographical distribution } \\
\hline & & 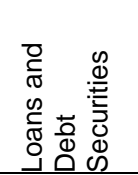 & 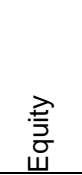 & 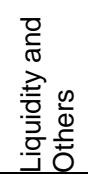 & as of (date) & $\begin{array}{l}\text { Central and } \\
\text { South America } \\
\text { and the } \\
\text { Caribbean }\end{array}$ & $\begin{array}{l}\text { Eastern } \\
\text { Europe and } \\
\text { Central } \\
\text { Asia }\end{array}$ & $\begin{array}{l}\text { South and } \\
\text { East Asia }\end{array}$ & $\begin{array}{l}\text { Middle East } \\
\text { and North } \\
\text { Africa }\end{array}$ & $\begin{array}{l}\text { Sub- } \\
\text { Saharan } \\
\text { Africa }\end{array}$ & $\begin{array}{l}\text { Western } \\
\text { Europe } \\
\text { and USA }\end{array}$ & $\begin{array}{l}\text { Funds } \\
\text { not } \\
\text { disbursed }\end{array}$ & as of (date) \\
\hline $\begin{array}{l}\text { responsAbility Global } \\
\text { Microfinance Fund }\end{array}$ & $\begin{array}{l}\text { EUR } \\
\text { USD }\end{array}$ & $67 \%$ & $6 \%$ & $27 \%$ & 30-Sep-10 & $42.8 \%$ & $38.6 \%$ & $16.2 \%$ & $0.6 \%$ & $1.8 \%$ & & & 30-Sep-10 \\
\hline $\begin{array}{l}\text { responsAbility Mikrofinanz } \\
\text { Fund }\end{array}$ & EUR & $82 \%$ & & $18 \%$ & 30-Sep-10 & $41.0 \%$ & $42.2 \%$ & $14.4 \%$ & $0.7 \%$ & $1.7 \%$ & & & 30-Sep-10 \\
\hline $\begin{array}{l}\text { responsAbility Microfinance } \\
\text { Leaders Fund }\end{array}$ & USD & $58 \%$ & $24 \%$ & $18 \%$ & 30-Sep-10 & $32.4 \%$ & $51.1 \%$ & $14.7 \%$ & & $1.8 \%$ & & & 30-Sep-10 \\
\hline $\begin{array}{l}\text { Dual Return - Vision } \\
\text { Microfinance Fund }\end{array}$ & $\begin{array}{l}\text { USD / Class P } \\
\text { EUR / Class P } \\
\text { EUR / Class I }\end{array}$ & $\begin{array}{l}\text { Based on } \\
\text { funds is }\end{array}$ & $\begin{array}{l}\text { fund's } \\
\text { invest }\end{array}$ & $\begin{array}{l}\text { prospe } \\
\text { d in de }\end{array}$ & $\begin{array}{l}\text { tus } 100 \% \text { of } \\
\text { t securities }\end{array}$ & $55 \%$ & $33 \%$ & $10 \%$ & & $2 \%$ & & & 27-Sep-10 \\
\hline $\begin{array}{l}\text { Dexia Micro-Credit Fund - } \\
\text { BlueOrchard Debt Sub-Fund }\end{array}$ & $\begin{array}{l}\text { EUR } \\
\text { USD }\end{array}$ & $82 \%$ & & $18 \%$ & $6-$-Oct-10 & $22 \%$ & $31 \%$ & $18 \%$ & $1 \%$ & $4 \%$ & $6 \%$ & $18 \%$ & $6-O c t-10$ \\
\hline $\begin{array}{l}\text { Edmond de Rothschild -Saint - } \\
\text { Honore Microfinance }\end{array}$ & EUR & $63 \%$ & & $37 \%$ & 1-Apr-10 & $38.0 \%$ & $27.7 \%$ & $34.3 \%$ & & & & & 1-Apr-10 \\
\hline BBVA Codespa Microfinanzas & EUR & $28 \%$ & & $72 \%$ & 31-Mar-10 & $100.0 \%$ & & & & & & & 1-Sep-10 \\
\hline $\begin{array}{l}\text { Wallberg Global Microfinance } \\
\text { Fund }\end{array}$ & $\begin{array}{l}\text { EUR / Class I } \\
\text { EUR / Class P }\end{array}$ & $85 \%$ & & $15 \%$ & 30-Jun-10 & $\mathrm{n} / \mathrm{a}$ & $\mathrm{n} / \mathrm{a}$ & $\mathrm{n} / \mathrm{a}$ & $\mathrm{n} / \mathrm{a}$ & $\mathrm{n} / \mathrm{a}$ & $\mathrm{n} / \mathrm{a}$ & $\mathrm{n} / \mathrm{a}$ & \\
\hline Dutch Microfund & EUR & $\begin{array}{r}\text { Based o } \\
50 \% \\
\text { investmen }\end{array}$ & $\begin{array}{l}\text { In fund } \\
\text { of func } \\
\text { th and } 5\end{array}$ & $\begin{array}{l}\text { s prosp } \\
\text { s goes } \\
0 \% \text { in c }\end{array}$ & $\begin{array}{l}\text { ectus about } \\
\text { n equity } \\
\text { ebt securities }\end{array}$ & $16 \%$ & $38 \%$ & $34 \%$ & $2 \%$ & $10 \%$ & & & Jan-10 \\
\hline $\begin{array}{l}\text { Erste-Sparinvest Espa Vinis } \\
\text { Microfinance }\end{array}$ & EUR & $\begin{array}{r}\text { Based o } \\
10 \%\end{array}$ & $\begin{array}{l}\text { on func } \\
\text { of fund } \\
\text { inv }\end{array}$ & $\begin{array}{l}\text { s prosp } \\
\text { can go } \\
\text { estment }\end{array}$ & $\begin{array}{l}\text { ectus up to } \\
\text { in equity }\end{array}$ & $\mathrm{n} / \mathrm{a}$ & $\mathrm{n} / \mathrm{a}$ & $\mathrm{n} / \mathrm{a}$ & $\mathrm{n} / \mathrm{a}$ & $\mathrm{n} / \mathrm{a}$ & $\mathrm{n} / \mathrm{a}$ & $\mathrm{n} / \mathrm{a}$ & \\
\hline Triodos Microfinance Fund & $\begin{array}{l}\text { EUR / Class I-cap } \\
\text { EUR / Class B-cap } \\
\text { EUR / Class B-dis } \\
\text { EUR / Class I-dis } \\
\text { EUR / Class R-cap }\end{array}$ & $58 \%$ & $21 \%$ & $21 \%$ & 30-Jun-10 & $\mathrm{n} / \mathrm{a}$ & $\mathrm{n} / \mathrm{a}$ & $\mathrm{n} / \mathrm{a}$ & $\mathrm{n} / \mathrm{a}$ & $\mathrm{n} / \mathrm{a}$ & $\mathrm{n} / \mathrm{a}$ & $\mathrm{n} / \mathrm{a}$ & \\
\hline $\begin{array}{l}\text { EMF Microfinance Fund } \\
\text { AGmvK }\end{array}$ & $\begin{array}{l}\text { USD / Class A } \\
\text { USD / Class T }\end{array}$ & $\mathrm{n} / \mathrm{a}$ & $\mathrm{n} / \mathrm{a}$ & $\mathrm{n} / \mathrm{a}$ & & $\mathrm{n} / \mathrm{a}$ & $\mathrm{n} / \mathrm{a}$ & $\mathrm{n} / \mathrm{a}$ & $\mathrm{n} / \mathrm{a}$ & $\mathrm{n} / \mathrm{a}$ & $\mathrm{n} / \mathrm{a}$ & $\mathrm{n} / \mathrm{a}$ & \\
\hline
\end{tabular}

Source: MIVs' websites and monthly or annual reports 
Table 3 - Monthly Returns Analysis

\begin{tabular}{|c|c|c|c|c|c|c|c|}
\hline MIV & Currency / Class & $\begin{array}{r}\text { Mean } \\
\text { Mo } \\
\mathbf{R e}\end{array}$ & $\begin{array}{l}\text { Median) } \\
\text { thly } \\
\text { urn }\end{array}$ & $\begin{array}{c}\text { Standard } \\
\text { Deviation } \\
\text { in Monthly } \\
\text { Returns }\end{array}$ & $\begin{array}{l}\text { Min } \\
\text { Monthly } \\
\text { Return }\end{array}$ & $\begin{array}{l}\text { Max } \\
\text { Monthly } \\
\text { Return }\end{array}$ & $\begin{array}{c}\text { Percentage } \\
\text { of Months } \\
\text { with } \\
\text { Negative } \\
\text { Returns }\end{array}$ \\
\hline \multicolumn{8}{|l|}{ Panel A: EUR denominated MIVs } \\
\hline responsAbility Global Microfinance Fund & EUR & $0.31 \%$ & {$[0.27 \%]$} & $0.38 \%$ & $-0.36 \%$ & $2.38 \%$ & $10.53 \%$ \\
\hline responsAbility Mikrofinanz Fund & EUR & $0.07 \%$ & [0.28\%] & $0.87 \%$ & $-4.10 \%$ & $0.61 \%$ & $10.00 \%$ \\
\hline Dual Return - Vision Microfinance Fund & EUR / Class P & $0.27 \%$ & [0.28\%] & $0.17 \%$ & $-0.19 \%$ & $0.66 \%$ & $5.66 \%$ \\
\hline Dual Return - Vision Microfinance Fund & EUR / Class I & $0.37 \%$ & [0.39\%] & $0.17 \%$ & $-0.14 \%$ & $0.72 \%$ & $5.56 \%$ \\
\hline $\begin{array}{l}\text { Dexia Micro-Credit Fund - BlueOrchard } \\
\text { Debt Sub-Fund }\end{array}$ & EUR & $0.31 \%$ & {$[0.34 \%]$} & $0.21 \%$ & $-0.29 \%$ & $0.90 \%$ & $7.02 \%$ \\
\hline $\begin{array}{l}\text { Edmond de Rothschild - Saint-Honore } \\
\text { Microfinance }\end{array}$ & EUR & $0.20 \%$ & [0.16\%] & $0.22 \%$ & $-0.12 \%$ & $0.80 \%$ & $17.54 \%$ \\
\hline BBVA Codespa Microfinanzas & EUR & $0.20 \%$ & {$[0.15 \%]$} & $0.91 \%$ & $-2.29 \%$ & $2.69 \%$ & $37.78 \%$ \\
\hline Wallberg Global Microfinance Fund & EUR / Class I & $0.24 \%$ & [0.22\%] & $0.21 \%$ & $-0.13 \%$ & $0.65 \%$ & $8.70 \%$ \\
\hline Wallberg Global Microfinance Fund & EUR / Class P & $0.08 \%$ & [0.28\%] & $1.02 \%$ & $-4.49 \%$ & $0.68 \%$ & $17.39 \%$ \\
\hline Dutch Microfund & EUR & $0.40 \%$ & {$[0.17 \%]$} & $1.55 \%$ & $-1.99 \%$ & $4.99 \%$ & $45.83 \%$ \\
\hline Erste-Sparinvest Espa Vinis Microfinance & EUR & $0.09 \%$ & [0.08\%] & $0.44 \%$ & $-0.64 \%$ & $0.90 \%$ & $37.50 \%$ \\
\hline Triodos Microfinance Fund & EUR / Class I-cap & $0.29 \%$ & [0.18\%] & $0.48 \%$ & $-0.54 \%$ & $1.31 \%$ & $23.53 \%$ \\
\hline Triodos Microfinance Fund & EUR / Class B-cap & $0.25 \%$ & [0.18\%] & $0.51 \%$ & $-0.62 \%$ & $1.25 \%$ & $40.00 \%$ \\
\hline Triodos Microfinance Fund & EUR / Class B-dis & $0.16 \%$ & [0.06\%] & $0.43 \%$ & $-0.59 \%$ & $1.26 \%$ & $40.00 \%$ \\
\hline Triodos Microfinance Fund & EUR / Class I-dis & $0.15 \%$ & {$[0.12 \%]$} & $0.46 \%$ & $-0.82 \%$ & $1.30 \%$ & $27.78 \%$ \\
\hline Triodos Microfinance Fund & EUR / Class R-cap & $0.27 \%$ & [0.20\%] & $0.52 \%$ & $-0.59 \%$ & $1.25 \%$ & $35.71 \%$ \\
\hline Median for EUR MIVs & & $0.24 \%$ & [0.19\%] & $0.45 \%$ & $-0.59 \%$ & $1.08 \%$ & $20.54 \%$ \\
\hline Mean for EUR MIVs & & $0.23 \%$ & [0.21\%] & $0.54 \%$ & $-1.12 \%$ & $1.40 \%$ & $23.16 \%$ \\
\hline \multicolumn{8}{|l|}{ Panel B: USD denominated MIVs } \\
\hline responsAbility Global Microfinance Fund & USD & $0.38 \%$ & {$[0.38 \%]$} & $0.40 \%$ & $-0.33 \%$ & $2.57 \%$ & $10.53 \%$ \\
\hline $\begin{array}{l}\text { responsAbility Microfinance Leaders } \\
\text { Fund }\end{array}$ & USD & $0.38 \%$ & [0.39\%] & $0.44 \%$ & $-0.51 \%$ & $2.14 \%$ & $13.04 \%$ \\
\hline Dual Return - Vision Microfinance Fund & USD / Class P & $0.23 \%$ & [0.34\%] & $1.64 \%$ & $-8.26 \%$ & $5.26 \%$ & $7.89 \%$ \\
\hline $\begin{array}{l}\text { Dexia Micro-Credit Fund - BlueOrchard } \\
\text { Debt Sub-Fund }\end{array}$ & USD & $0.37 \%$ & {$[0.40 \%]$} & $0.26 \%$ & $-0.19 \%$ & $1.11 \%$ & $7.02 \%$ \\
\hline EMF Microfinance Fund AGmvK & USD / Class A & $0.11 \%$ & {$[0.33 \%]$} & $0.89 \%$ & $-3.94 \%$ & $0.44 \%$ & $8.70 \%$ \\
\hline EMF Microfinance Fund AGmvK & USD / Class T & $0.30 \%$ & {$[0.33 \%]$} & $0.12 \%$ & $-0.11 \%$ & $0.44 \%$ & $4.35 \%$ \\
\hline Median for USD MIVs & & $0.34 \%$ & {$[0.36 \%]$} & $0.42 \%$ & $-0.42 \%$ & $1.63 \%$ & $8.30 \%$ \\
\hline Mean for USD MIVs & & $0.30 \%$ & {$[0.36 \%]$} & $0.62 \%$ & $-2.22 \%$ & $1.99 \%$ & $8.59 \%$ \\
\hline \multicolumn{8}{|c|}{ Panel C: Benchmark indices (incl. risk-free rate) } \\
\hline MSCI World Index & & $0.05 \%$ & {$[1.07 \%]$} & $5.62 \%$ & $-19.04 \%$ & $10.90 \%$ & $47.37 \%$ \\
\hline MSCI Emerging Markets Index & & $1.09 \%$ & [0.96\%] & $8.25 \%$ & $-27.50 \%$ & $16.66 \%$ & $40.35 \%$ \\
\hline Markit iBoxx EUR Liquid Corporates Bond & Index & $0.31 \%$ & [0.30\%] & $1.32 \%$ & $-4.78 \%$ & $3.66 \%$ & $38.60 \%$ \\
\hline J.P. Morgan Emerging Bond Index & & $0.79 \%$ & [1.07\%] & $2.97 \%$ & $-13.79 \%$ & $8.52 \%$ & $26.32 \%$ \\
\hline 10Y German Government Bonds & & $0.30 \%$ & [0.31\%] & $0.05 \%$ & $0.18 \%$ & $0.38 \%$ & not \\
\hline 10Y U.S. Government Bonds & & $0.33 \%$ & [0.32\%] & $0.06 \%$ & $0.18 \%$ & $0.43 \%$ & applicable \\
\hline
\end{tabular}

Notes: All returns calculations of monthly returns are based on simple return formula as depicted by equation 2 .

Source: own calculations based on data from Bloomberg and Markit 


\section{Table 4 - Total p.a. Returns of Microfinance Investment Funds}

and Benchmark Indices

\begin{tabular}{|c|c|c|c|c|c|c|c|}
\hline \multirow{2}{*}{ MIV } & \multirow{2}{*}{ Currency / Class } & \multicolumn{5}{|c|}{ Total return p.a. } & \multirow{2}{*}{$\begin{array}{c}\text { Total return } \\
\text { from } 2006 \\
\text { (or } \\
\text { inception) } \\
\end{array}$} \\
\hline & & 2006 & 2007 & 2008 & 2009 & $2010^{*}$ & \\
\hline \multicolumn{8}{|l|}{ Panel A: EUR denominated MIVs } \\
\hline$\overline{\text { responsAbility Global Microfinance Fund }}$ & EUR & $2.70 \%$ & $6.31 \%$ & $6.88 \%$ & $1.09 \%$ & $1.29 \%$ & $19.48 \%$ \\
\hline responsAbility Mikrofinanz Fund & EUR & n.a. & $2.15 \%$ & $3.64 \%$ & $-2.01 \%$ & $-1.20 \%$ & $2.50 \%$ \\
\hline Dual Return - Vision Microfinance Fund & EUR / Class P & $0.45 \%$ & $3.11 \%$ & $5.60 \%$ & $3.27 \%$ & $1.87 \%$ & $15.07 \%$ \\
\hline al Return - Vision Microfinance Fund & EUR / Class I & n.a. & $1.17 \%$ & $6.30 \%$ & $3.94 \%$ & $2.34 \%$ & $14.39 \%$ \\
\hline $\begin{array}{l}\text { Dexia Micro-Credit Fund - BlueOrchard } \\
\text { Debt Sub-Fund }\end{array}$ & EUR & $4.21 \%$ & $4.83 \%$ & $5.90 \%$ & $2.42 \%$ & $0.70 \%$ & $19.32 \%$ \\
\hline $\begin{array}{l}\text { Edmond de Rothschild - Saint-Honore } \\
\text { Microfinance }\end{array}$ & EUR & $2.04 \%$ & $2.27 \%$ & $3.93 \%$ & $2.79 \%$ & $0.47 \%$ & $12.00 \%$ \\
\hline BBVA Codespa Microfinanzas & EUR & n.a. & $2.24 \%$ & $6.65 \%$ & $-0.69 \%$ & $0.73 \%$ & $9.08 \%$ \\
\hline Wallberg Global Microfinance Fund & EUR / Class I & n.a. & n.a. & $-0.12 \%$ & $3.95 \%$ & $1.83 \%$ & $5.73 \%$ \\
\hline Wallberg Global Microfinance Fund & EUR / Class P & n.a. & n.a. & $-0.17 \%$ & $4.60 \%$ & $-2.66 \%$ & $1.64 \%$ \\
\hline Dutch Microfund & EUR & n.a. & n.a. & $2.64 \%$ & $2.98 \%$ & $3.78 \%$ & $9.70 \%$ \\
\hline Erste-Sparinvest Espa Vinis Microfinance & EUR & n.a. & n.a. & n.a. & n.a. & $0.75 \%$ & $0.75 \%$ \\
\hline Triodos Microfinance Fund & EUR / Class I-cap & n.a. & n.a. & n.a. & $1.08 \%$ & $3.60 \%$ & $4.72 \%$ \\
\hline Triodos Microfinance Fund & EUR / Class B-cap & n.a. & n.a. & n.a. & $0.32 \%$ & $3.14 \%$ & $3.47 \%$ \\
\hline Triodos Microfinance Fund & EUR / Class B-dis & n.a. & n.a. & n.a. & $0.32 \%$ & $1.91 \%$ & $2.23 \%$ \\
\hline Triodos Microfinance Fund & EUR / Class I-dis & n.a. & n.a. & n.a. & $1.20 \%$ & $1.42 \%$ & $2.64 \%$ \\
\hline Triodos Microfinance Fund & EUR / Class R-cap & n.a. & n.a. & n.a. & $0.44 \%$ & $3.11 \%$ & $3.56 \%$ \\
\hline Median for EUR MIVs & & $2.37 \%$ & $2.27 \%$ & $4.77 \%$ & $1.20 \%$ & $1.63 \%$ & $5.22 \%$ \\
\hline Mean for EUR MIVs & & $2.35 \%$ & $3.15 \%$ & $4.13 \%$ & $1.71 \%$ & $1.44 \%$ & $7.89 \%$ \\
\hline \multicolumn{8}{|l|}{ Panel B: USD denominated MIVs } \\
\hline responsAbility Global Microfinance Fund & USD & $5.07 \%$ & $7.70 \%$ & $6.44 \%$ & $1.16 \%$ & $1.60 \%$ & $23.79 \%$ \\
\hline $\begin{array}{l}\text { responsAbility Microfinance Leaders } \\
\text { Fund }\end{array}$ & USD & $0.34 \%$ & $6.03 \%$ & $7.51 \%$ & $1.74 \%$ & $2.46 \%$ & $19.23 \%$ \\
\hline Dual Return - Vision Microfinance Fund & USD / Class P & $1.70 \%$ & $5.51 \%$ & $4.31 \%$ & $-2.94 \%$ & n.a & $8.63 \%$ \\
\hline $\begin{array}{l}\text { Dexia Micro-Credit Fund - BlueOrchard } \\
\text { Debt Sub-Fund }\end{array}$ & USD & $6.90 \%$ & $5.89 \%$ & $5.64 \%$ & $2.25 \%$ & $0.81 \%$ & $23.27 \%$ \\
\hline EMF Microfinance Fund AGmvK & USD / Class A & n.a. & n.a. & $0.03 \%$ & $4.37 \%$ & $-1.74 \%$ & $2.58 \%$ \\
\hline EMF Microfinance Fund AGmvK & USD / Class T & n.a. & n.a. & $0.03 \%$ & $4.37 \%$ & $2.73 \%$ & $7.25 \%$ \\
\hline Median for USD MIVs & & $3.38 \%$ & $5.96 \%$ & $4.98 \%$ & $2.00 \%$ & $1.60 \%$ & $13.93 \%$ \\
\hline Mean for USD MIVs & & $3.50 \%$ & $6.28 \%$ & $3.99 \%$ & $1.82 \%$ & $1.17 \%$ & $14.13 \%$ \\
\hline \multicolumn{8}{|l|}{ Panel C: Benchmark indices } \\
\hline MSCI World Index & & $17.95 \%$ & $7.09 \%$ & $-42.08 \%$ & $26.98 \%$ & $0.92 \%$ & $-6.25 \%$ \\
\hline MSCI Emerging Markets Index & & $29.18 \%$ & $36.48 \%$ & $-54.48 \%$ & $74.50 \%$ & $8.70 \%$ & $52.24 \%$ \\
\hline \multicolumn{2}{|c|}{ Markit iBoxx EUR Liquid Corporates Bond Index } & $0.40 \%$ & $-0.24 \%$ & $-3.99 \%$ & $16.02 \%$ & $6.55 \%$ & $18.88 \%$ \\
\hline J.P. Morgan Emerging Bond Index & & $10.48 \%$ & $6.45 \%$ & $-9.70 \%$ & $25.95 \%$ & $14.46 \%$ & $53.10 \%$ \\
\hline
\end{tabular}

Notes: *returns for 2010 are calculated for the time span from January 1, 2010 until September 30, 2010. All returns calculations of monthly and per annum returns are based on simple return formula as depicted by equation 2 .

Source: own calculations based on data from Bloomberg and Markit 
Table 5 - Correlation Matrix of Historical Excess Returns

\section{Panel A: Excess returns over yield on $10 Y$ German government bond

Panela:Excess returns over yield on 10r Germangovernment bond

\begin{tabular}{llrrrrr} 
(1) & MSCI World Index & 1.00 & \multicolumn{3}{c}{} \\
(2) & MSCI Emerging Markets Index & 0.92 & 1.00 & & \\
(3) & Markit iBoxx EUR Liquid Corporates Bond Index & 0.50 & 0.47 & 1.00 & \\
(4) & J.P. Morgan Emerging Bond Index & 0.73 & 0.74 & 0.68 & 1.00 \\
(5) & EUR denominated MIV portfolio & -0.51 & -0.49 & -0.32 & -0.38 & 1.00
\end{tabular}

\section{Panel B: Excess returns over yield on $10 Y$ U.S. government bond}

\begin{tabular}{llrrrrr}
\hline & & (1) & (2) & (3) & (4) & (5) \\
\hline (1) & MSCI World Index & 1.00 & & & & \\
(2) & MSCI Emerging Markets Index & 0.92 & 1.00 & & & \\
(3) & Markit iBoxx EUR Liquid Corporates Bond Index & 0.49 & 0.47 & 1.00 & & \\
(4) & J.P. Morgan Emerging Bond Index & 0.73 & 0.74 & 0.68 & 1.00 & \\
(5) & USD denominated MIV portfolio & -0.14 & -0.17 & -0.31 & -0.20 & 1.00 \\
\hline
\end{tabular}

Notes: Correlation coefficients are calculated on excess monthly returns (adjusted by return on respective risk-free assets) from January 1, 2010 until September 30, 2010. Monthly returns calculations are based on natural log return formula as depicted by equation 3 .

Source: own calculations based on data from Bloomberg and Markit

Table 6 - Cross-sectional Regression Tests

\begin{tabular}{cccc}
\hline MSCI World Index & $\begin{array}{c}\text { MSCl Emerging } \\
\text { Markets Index }\end{array}$ & $\begin{array}{c}\text { Markit iBoxx EUR } \\
\text { Liquid Corporates } \\
\text { Bond Index }\end{array}$ & $\begin{array}{c}\text { J.P. Morgan } \\
\text { Emerging Bond } \\
\text { Index }\end{array}$ \\
\hline
\end{tabular}

Panel A: F-test for fixed group effects

\begin{tabular}{lllll}
\hline & p-value & p-value & p-value & p-value \\
EUR denominated MIVs & 0.7859 & 0.7995 & 0.7666 & 0.7954 \\
USD denominated MIVs & 0.6990 & 0.7138 & 0.7887 & 0.7520
\end{tabular}

Panel B: Breusch and Pagan Lagrangian multiplier (LM) test for random effects

\begin{tabular}{lllll}
\hline & $\underline{p}$-value & $\underline{p}$-value & $\underline{p}$-value & $\underline{p}$-value \\
EUR denominated MIVs & 0.5793 & 0.5487 & 0.5720 & 0.5527 \\
USD denominated MIVs & 0.3459 & 0.3348 & 0.2869 & 0.3095 \\
\hline
\end{tabular}

Notes: The null hypothesis of the F-test of joint significance of differing group intercepts is that the cross-sectional units all have a common intercept (in which case the pooled regression model is appropriate) against the alternative favoring the use of fixed effects model.

The null hypothesis of the Breusch and Pagan LM test for one-way random group effects is that cross-sectional variance components are zero. If the null hypothesis is not rejected, the pooled regression model is appropriate (otherwise the random effects model is preferred).

Source: own calculations based on data from Bloomberg and Markit 
Table 7 - Tests for Heteroskedasticity and Autocorrelation

\begin{tabular}{|c|c|c|c|c|}
\hline & MSCI World Index & $\begin{array}{l}\text { MSCI Emerging } \\
\text { Markets Index }\end{array}$ & $\begin{array}{l}\text { Markit iBoxx EUR } \\
\text { Liquid Corporates } \\
\text { Bond Index }\end{array}$ & $\begin{array}{l}\text { J.P. Morgan } \\
\text { Emerging Bond } \\
\text { Index }\end{array}$ \\
\hline \multicolumn{5}{|c|}{ Panel A: Breusch-Pagan/Cook-Weisberg test for heteroskedasticity } \\
\hline & p-value & p-value & p-value & p-value \\
\hline EUR denominated MIVs & 0.5380 & 0.8756 & 0.3174 & 0.4804 \\
\hline USD denominated MIVs & 0.1505 & 0.1167 & 0.1064 & 0.1955 \\
\hline \multicolumn{5}{|c|}{ Panel B: White's test for heteroskedasticity } \\
\hline & p-value & p-value & p-value & $\underline{p \text {-value }}$ \\
\hline EUR denominated MIVs & 0.7924 & 0.9644 & 0.6022 & 0.7743 \\
\hline USD denominated MIVs & 0.0193 & 0.0388 & 0.0478 & 0.2188 \\
\hline \multicolumn{5}{|c|}{ Panel C: Modified Wald Test for groupwise heteroskedasticity } \\
\hline & p-value & p-value & p-value & $\underline{p-v a l u e ~}$ \\
\hline EUR denominated MIVs & 0.0000 & 0.0000 & 0.0000 & 0.0000 \\
\hline USD denominated MIVs & 0.0000 & 0.0000 & 0.0000 & 0.0000 \\
\hline \multicolumn{5}{|c|}{ Panel D: Wooldridge test for autocorrelation in panel data } \\
\hline & p-value & p-value & p-value & p-value \\
\hline EUR denominated MIVs & 0.3316 & 0.3047 & 0.3634 & 0.312 \\
\hline USD denominated MIVs & 0.0085 & 0.0093 & 0.0278 & 0.0110 \\
\hline
\end{tabular}

Notes: The null hypothesis of the Breusch-Pagan/Cook-Weisberg test is that the error variances are all equal versus the alternative that the error variances are a multiplicative function of one or more variables. Panel A shows $p$-values for modified Breusch-Pagan/Cook-Weisberg test, which drops the assumption of normal distribution of the regression disturbances.

The Breusch-Pagan/Cook-Weisberg test does not work well for non-linear forms of heteroskedasticity. For that reason we use the White's general test for heteroskedasticity in Panel B. The null hypothesis of the White's general test is equal error variances.

The null hypothesis of the modified Wald statistic for groupwise heteroskedasticity in Panel C is common error variance of cross-sections. The modified Wald statistic is workable (in asymptotic terms) when the assumption of normality is violated.

The null hypothesis of Wooldridge test for serial correlation in errors of linear panel-data models in Panel $D$ is no first-order autocorrelation.

For figures in bold we reject the null hypotheses on chosen 5 percent level of significance.

Source: own calculations based on data from Bloomberg and Markit 
Table 8 - Portfolio Betas and R-Squared

\begin{tabular}{|c|c|c|c|c|c|c|c|c|c|c|c|c|}
\hline & \multicolumn{3}{|c|}{ MSCI World Index } & \multicolumn{3}{|c|}{$\begin{array}{l}\text { MSCI Emerging } \\
\text { Markets Index }\end{array}$} & \multicolumn{3}{|c|}{$\begin{array}{l}\text { Markit iBoxx EUR } \\
\text { Liquid Corporates } \\
\text { Bond Index }\end{array}$} & \multicolumn{3}{|c|}{$\begin{array}{l}\text { J.P. Morgan } \\
\text { Emerging Bond Index }\end{array}$} \\
\hline \multicolumn{13}{|c|}{ Panel A: cross-sectional regression } \\
\hline & Beta & & $\underline{\mathrm{R} \text {-sq. }}$ & Beta & & $\underline{\mathrm{R} \text {-sq. }}$ & Beta & & $\underline{\mathrm{R} \text {-sq. }}$ & Beta & & $\underline{\mathrm{R} \text {-sq. }}$. \\
\hline EUR denominated MIVs & -0.0200 & *** & $4.29 \%$ & -0.0145 & $* * *$ & $4.24 \%$ & -0.0691 & ** & $3.08 \%$ & -0.0343 & $* * *$ & $3.43 \%$ \\
\hline USD denominated MIVs & -0.0145 & & $0.85 \%$ & -0.0115 & * & $1.25 \%$ & -0.1093 & $* \star \star *$ & $3.85 \%$ & -0.0338 & * & $1.28 \%$ \\
\hline \multicolumn{13}{|c|}{ Panel B: equally-weighted portfolio regression } \\
\hline & Beta & & $\underline{\mathrm{R} \text {-sq. }}$ & Beta & & $\underline{\mathrm{R} \text {-sq. }}$ & Beta & & $\underline{\mathrm{R} \text {-sq. }}$ & Beta & & $\underline{\mathrm{R} \text {-sq. }}$ \\
\hline EUR denominated MIVs & -0.0198 & $* * *$ & $26.48 \%$ & -0.0129 & $* * *$ & $24.31 \%$ & -0.0531 & $* * *$ & $10.23 \%$ & -0.0278 & $* * *$ & $14.49 \%$ \\
\hline USD denominated MIVs & -0.0078 & & $1.94 \%$ & -0.0065 & & $2.91 \%$ & -0.0737 & & $9.42 \%$ & -0.0212 & * & $4.03 \%$ \\
\hline
\end{tabular}

Notes: Panel A reports results obtained by cross-sectional regression of risk-free rate adjusted monthly returns of microfinance funds in given currency against four selected market portfolios. Equation 1 is estimated using panel-corrected standard errors (PCSEs). Panel B refers to the same type of estimates obtained by regressing risk-free rate adjusted returns of the equallyweighted portfolio of microfinance funds in given currency on adjusted returns of market benchmarks. Equation 1 is estimated using OLS regression with heteroskedasticity and autocorrelation consistent (HAC) standard errors.

For each index there are estimates of the beta coefficient in the first column, ${ }^{* * *} / * * *$ in the second column represent significance at $10 \%, 5 \%$ and $1 \%$ level. R-squared results are in the third column for each market benchmark.

Source: own calculations based on data from Bloomberg and Markit

Table 9 - Jensen's Alphas

\begin{tabular}{|c|c|c|c|c|c|c|c|c|}
\hline & \multicolumn{2}{|c|}{$\begin{array}{l}\text { MSCI World } \\
\text { Index }\end{array}$} & \multicolumn{2}{|c|}{$\begin{array}{l}\text { MSCI Emerging } \\
\text { Markets Index }\end{array}$} & \multicolumn{2}{|c|}{$\begin{array}{l}\text { Markit iBoxx EUR } \\
\text { Liquid Corporates } \\
\text { Bond Index }\end{array}$} & \multicolumn{2}{|c|}{$\begin{array}{l}\text { J.P. Morgan } \\
\text { Emerging Bond } \\
\text { Index }\end{array}$} \\
\hline \multicolumn{9}{|c|}{ Panel A: cross-sectional regression } \\
\hline & Alpha & & Alpha & & Alpha & & Alpha & \\
\hline EUR denominated MIVs & $0.22 \%$ & *** & $0.23 \%$ & $\star * *$ & $0.24 \%$ & $* \star *$ & $0.25 \%$ & *** \\
\hline USD denominated MIVs & $0.28 \%$ & *** & $0.29 \%$ & 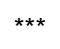 & $0.30 \%$ & $* \star \star$ & $0.31 \%$ & *** \\
\hline \multicolumn{9}{|c|}{ Panel B: equally-weighted portfolio regression } \\
\hline & Alpha & & Alpha & & Alpha & & Alpha & \\
\hline EUR denominated MIVs & $-0.045 \%$ & * & $-0.031 \%$ & & $-0.036 \%$ & & $-0.024 \%$ & \\
\hline USD denominated MIVs & $0.018 \%$ & & $0.024 \%$ & & $0.019 \%$ & & $0.030 \%$ & \\
\hline
\end{tabular}

Notes: Panel A reports estimate of constant obtained by cross-sectional regression of risk-free rate adjusted monthly returns of microfinance funds in given currency against four selected market portfolios. Equation 1 is estimated using panelcorrected standard errors (PCSEs). Panel B refers to the same type of estimates obtained by regressing risk-free rate adjusted returns of the equally-weighted portfolio of microfinance funds in given currency on adjusted returns of market benchmarks. Equation 1 is estimated using OLS regression with heteroskedasticity and autocorrelation consistent (HAC) standard errors.

Alpha estimates are expressed in percentage revealing the added monthly return of microfinance funds compared to its theoretical expected return implied by the CAPM that compensate an investor for the systematic risk measured by beta. Levels of significance are for each index in the second column $-^{* / * * / * \star *}$ represent significance at $10 \%, 5 \%$ and $1 \%$ level.

Source: own calculations based on data from Bloomberg and Markit 
Table 10 - Chow Test

\begin{tabular}{lcc}
\hline \hline & MSCI World Index & MSCI Emerging Markets Index \\
\hline Panel A: cross-sectional regression & & p-value \\
EUR denominated MIVs & $\frac{\mathrm{p} \text {-value }}{6.7 \mathrm{E}-09}$ & $5.0 \mathrm{E}-08$ \\
USD denominated MIVs & 0.0001 & 0.0001 \\
Panel B: equally-weighted portfolio regression & & \\
& $\underline{\mathrm{p} \text {-value }}$ & $\mathrm{p}$-value \\
EUR denominated MIVs & 0.0273 & 0.0460 \\
USD denominated MIVs & 0.0341 & 0.0496 \\
\hline
\end{tabular}

Notes: The null hypothesis of the Chow test is stability of regression parameters throughout the study period from January 2006 until September 2010, i.e. no structural break in data series. For figures in bold we reject the null hypothesis of parameters' structural stability on chosen 5 percent level of significance.

Source: own calculations based on data from Bloomberg and Markit

Table 11 - Regression Results for Submodels

\begin{tabular}{|c|c|c|c|c|c|c|c|c|c|}
\hline & & \multicolumn{4}{|c|}{ MSCI World Index } & \multicolumn{4}{|c|}{ MSCI Emerging Markets Index } \\
\hline \multicolumn{10}{|c|}{ Panel A: cross-sectional regression } \\
\hline & $\underline{\text { Time period }}$ & Alpha & & Beta & & Alpha & & Beta & \\
\hline \multirow[t]{3}{*}{ EUR denominated MIVs } & Jan 2006 - Oct 2007 & $0.31 \%$ & $* * *$ & -0.0516 & ** & $0.33 \%$ & *** & -0.0206 & *** \\
\hline & Nov 2007 - Feb 2009 & $0.32 \%$ & $* * *$ & -0.0323 & *** & $0.38 \%$ & *** & -0.0178 & *** \\
\hline & Mar 2009 - Sep 2010 & $0.14 \%$ & ** & 0.0010 & & $0.13 \%$ & ** & 0.0021 & \\
\hline \multirow[t]{3}{*}{ USD denominated MIVs } & Jan 2006 - Oct 2007 & $0.52 \%$ & *** & -0.0203 & & $0.52 \%$ & $* * *$ & -0.0093 & \\
\hline & Nov 2007 - Feb 2009 & $0.36 \%$ & *** & -0.0088 & & $0.35 \%$ & $\star \star * *$ & -0.0085 & * \\
\hline & Mar 2009 - Sep 2010 & $0.03 \%$ & & 0.0015 & & $0.06 \%$ & & -0.0063 & \\
\hline \multicolumn{10}{|c|}{ Panel B: equally-weighted portfolio regression } \\
\hline & $\underline{\text { Time period }}$ & Alpha & & Beta & & Alpha & & Beta & \\
\hline \multirow[t]{3}{*}{ EUR denominated MIVs } & Jan 2006 - Oct 2007 & $-0.05 \%$ & & -0.0226 & & $-0.05 \%$ & & -0.0107 & \\
\hline & Nov 2007 - Feb 2009 & $-0.02 \%$ & & -0.0257 & *** & $0.02 \%$ & & -0.0146 & *** \\
\hline & Mar 2009 - Sep 2010 & $-0.12 \%$ & ** & -0.0016 & & $-0.12 \%$ & ** & -0.0003 & \\
\hline \multirow[t]{3}{*}{ USD denominated MIVs } & Jan 2006 - Oct 2007 & $0.08 \%$ & ** & -0.0144 & & $0.08 \%$ & * & -0.0036 & \\
\hline & Nov 2007 - Feb 2009 & $0.08 \%$ & $* * *$ & -0.0093 & & $0.08 \%$ & ** & -0.0072 & ** \\
\hline & Mar 2009 - Sep 2010 & $-0.15 \%$ & * & 0.0130 & & $-0.15 \%$ & & 0.0069 & \\
\hline
\end{tabular}

Notes: Panel A reports the estimate of constant and beta obtained by cross-sectional regression of equation 1 separately for three above described time periods against two stock market indices using panel-corrected standard errors (PCSEs). Panel B refers to the same type of estimates obtained by equally-weighted portfolio approach. Equation 1 is estimated using OLS regression with heteroskedasticity and autocorrelation consistent (HAC) standard errors.

Alpha estimates are expressed in percentages revealing the added monthly return of microfinance funds over its theoretical expected return implied by the CAPM that compensates an investor for the systematic risk measured by beta. ${ }^{* / *}{ }^{* \star *}$ represent significance at $10 \%, 5 \%$ and $1 \%$ level.

Source: own calculations based on data from Bloomberg and Markit 


\section{Working Paper Series}

ISSN 1211-3298

Registration No. (Ministry of Culture): E 19443

Individual researchers, as well as the on-line and printed versions of the CERGE-EI Working Papers (including their dissemination) were supported from institutional support RVO 67985998 from Economics Institute of the ASCR, v. v. i.

Specific research support and/or other grants the researchers/publications benefited from are acknowledged at the beginning of the Paper.

(c) Karel Janda and Barbora Svárovská, 2012

All rights reserved. No part of this publication may be reproduced, stored in a retrieval system or transmitted in any form or by any means, electronic, mechanical or photocopying, recording, or otherwise without the prior permission of the publisher.

Published by

Charles University in Prague, Center for Economic Research and Graduate Education (CERGE) and

Economics Institute ASCR, v. v. i. (EI)

CERGE-El, Politických vězňů 7, 11121 Prague 1, tel.: +420 224005 153, Czech Republic.

Printed by CERGE-EI, Prague

Subscription: CERGE-EI homepage: http://www.cerge-ei.cz

Phone: + 420224005153

Email: office@cerge-ei.cz

Web: http://www.cerge-ei.cz

Editor: Michal Kejak

The paper is available online at http://www.cerge-ei.cz/publications/working_papers/.

ISBN 978-80-7343-274-4 (Univerzita Karlova. Centrum pro ekonomický výzkum a doktorské studium)

ISBN 978-80-7344-266-8 (Národohospodářský ústav AV ČR, v. v. i.) 


\section{Working Paper Series}

ISSN 1211-3298

Registration No. (Ministry of Culture): E 19443

Individual researchers, as well as the on-line and printed versions of the CERGE-EI Working Papers (including their dissemination) were supported from institutional support RVO 67985998 from Economics Institute of the ASCR, v. v. i.

Specific research support and/or other grants the researchers/publications benefited from are acknowledged at the beginning of the Paper.

(c) Karel Janda and Barbora Svárovská, 2012

All rights reserved. No part of this publication may be reproduced, stored in a retrieval system or transmitted in any form or by any means, electronic, mechanical or photocopying, recording, or otherwise without the prior permission of the publisher.

Published by

Charles University in Prague, Center for Economic Research and Graduate Education (CERGE) and

Economics Institute ASCR, v. v. i. (EI)

CERGE-El, Politických vězňů 7, 11121 Prague 1, tel.: +420 224005 153, Czech Republic.

Printed by CERGE-EI, Prague

Subscription: CERGE-EI homepage: http://www.cerge-ei.cz

Phone: + 420224005153

Email: office@cerge-ei.cz

Web: http://www.cerge-ei.cz

Editor: Michal Kejak

The paper is available online at http://www.cerge-ei.cz/publications/working_papers/.

ISBN 978-80-7343-274-4 (Univerzita Karlova. Centrum pro ekonomický výzkum a doktorské studium)

ISBN 978-80-7344-266-8 (Národohospodářský ústav AV ČR, v. v. i.) 
CERGE-EI

P.O.BOX 882

Politických vězňů 7

11121 Praha 1

Czech Republic http://www.cerge-ei.cz 